\title{
DIVERSIDADE DE TÉRMITAS EM CULTIVOS DE EUCALIPTO E FRAGMENTOS FLORESTAIS NA ESTAÇÃO EXPERIMENTAL DE CIÊNCIAS FLORESTAIS - ESALQ/USP, ANHEMBI, SP
}

\section{LUCIANE KERN JUNQUEIRA}

\author{
Tese apresentada à Escola Superior de \\ Agricultura "Luiz de Queiroz", Universidade de \\ São Paulo, para obtenção do Título de Doutor \\ em Recursos Florestais, com opção em \\ Silvicultura e Manejo Florestal.
}

PIR A CICAB A

Estado de São Paulo - Brasil

Maio - 2004 


\title{
DIVERSIDADE DE TÉRMITAS EM CULTIVOS DE EUCALIPTO E FRAGMENTOS FLORESTAIS NA ESTAÇÃO EXPERIMENTAL DE CIÊNCIAS FLORESTAIS - ESALQ/USP, ANHEMBI, SP
}

\section{LUCIANE KERN JUNQUEIRA \\ Bióloga}

Orientador: Prof. Dr. EVONEO BERTI FILHO

\author{
Tese apresentada à Escola Superior de \\ Agricultura "Luiz de Queiroz", Universidade de \\ São Paulo, para obtenção do Título de Doutor \\ em Recursos Florestais, com opção em \\ Silvicultura e Manejo Florestal.
}

PIR A CICAB A

Estado de São Paulo - Brasil

Maio - 2004 


\section{Dados Internacionais de Catalogação na Publicação (CIP)}

DIVISÃO DE BIBLIOTECA E DOCUMENTAÇÃO - ESALQ/USP

\section{Junqueira, Luciane Kern}

Diversidade de térmitas em cultivos de eucalipto e fragmentos florestais na Estação Experimental de Ciências Florestais - ESALQ/USP, Anhembi, SP / Luciane Kern Junqueira. - - Piracicaba, 2004.

76 p. : il.

Tese (doutorado) - - Escola Superior de Agricultura Luiz de Queiroz, 2004. Bibliografia.

1. Análise de variância 2. Biodiversidade 3. Cupim (Controle) 4. Desmatamento 5. Eucalipto 6. Florestas 7. Zoologia (Classificação) I. Título

CDD 634.9734 
Valeu a pena? Tudo vale a pena

Se a alma não é pequena.

Quem passar além de Bojador

Tem que passar além da dor.

Deus ao mar o perigo e o abismo deu,

Mas nele é que espelhou o céu.

MarPortuguês

Fernando Pessoa 


\title{
A Deus,
}

que traça nossa trajetória nesta vida, mas

que sempre nos dá a oportunidade de escolha,

obrigada por me iluminar na decisão certa.

$$
\text { Agradeço }
$$

Aos meus pais,

pelo incentivo e por acreditarem que eu poderia ir um pouco mais longe, não negando esforços para que isto acontecesse. Todas as conquistas são devidas à educação $e$ às oportunidades que vocês proporcionaram.

Dedico

\begin{abstract}
À Elena, por estar sempre ao meu lado nos momentos mais difíceis da minha vida, pela grande amizade, carinho, companheirismo e exemplo.
\end{abstract}




\section{AGRADECIMENTOS}

- Ao prof. Dr. Evoneo Berti Filho, obrigada pela amizade da sua família, pelo companheirismo e alegria constantes, pelos conhecimentos transmitidos e pela paciência em corrigir meus erros.

- Ao grande amigo Paulo Bogorni, não tenho palavras para agradecer o quanto a tua amizade significou nesta jornada.

- A Eduardo Diehl Fleig pela amizade e alegre convivência, por auxiliar-me sempre que foi necessário.

- À Daniela e Thaís, sem vocês este trabalho não estaria finalizado, obrigado pelo auxílio inestimável nos trabalhos de campo e laboratório e, principalmente, pela grande amizade e companheirismo gerados por esta convivência.

- Aos novos amigos, Ana, Rubinho e Vanessa, que vivenciaram o final desta trajetória, compreendendo o tempo que não pude dedicar a vocês.

- Ao Dr. Carlos Alberto Silva, amigo e colega, por sempre acreditar e incentivar meus propósitos pessoais e profissionais. 
- Às amigas separadas pela distância, mas não no coração: Luciane, Cássia , Emília, Eunice, Franciele, Gláucia, Letícia, Lisiane, Márcia, Rafaela e Renata. Obrigada pela amizade e palavras de conforto nos momento difíceis e pela companhia e sorriso nos momentos alegres.

- Aos professores e colegas do Departamento de Ciências Florestais e do Departamento de Entomologia, Fitopatologia e Zoologia Agrícola, obrigada pelo companheirismo e auxílio durante a elaboração deste trabalho

- Aos colegas da UNIMEP pelo incentivo.

- Ao Dr. Luiz Roberto Fontes, agradeço o auxílio na identificação do material e pelos ensinamentos taxonômicos e sistemáticos transmitidos.

- Ao prof. Dr. Sinval Silveira Neto pelo auxílio estatístico.

- Aos funcionários e estagiários da Estação Experimental de Ciências Florestais de Anhembi, obrigado pelo empenho e tempo dedicados a realização deste projeto. Sem o auxílio de vocês seria impossível ultrapassar as dificuldades do trabalho em campo.

- Aos Departamentos de Ciências Florestais e Entomologia, Fitopatologia e Zoologia Agrícola, pela utilização do Laboratório de Entomologia Florestal e pela disponibilidade de transporte semanal à Estação Experimental de Ciências Florestais, em Anhembi.

- A CAPES pela concessão da bolsa de Doutorado. 


\section{SUMÁRIO}

Página

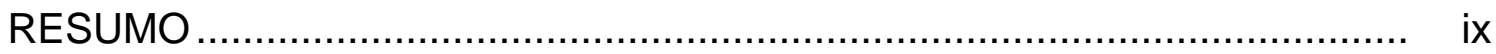

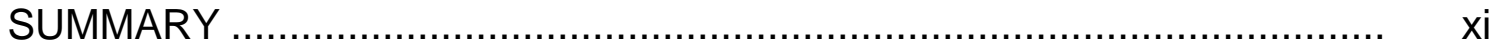

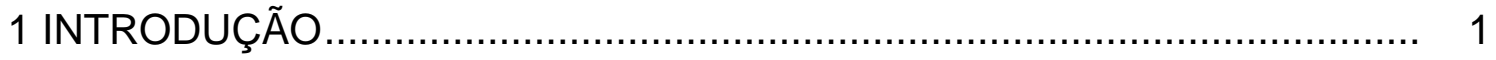

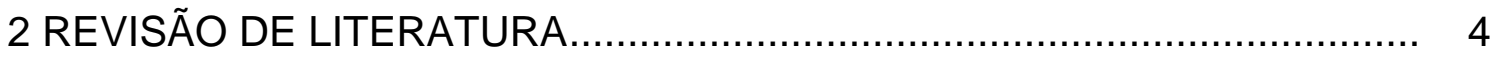

2.1 Considerações gerais sobre os térmitas ............................................... 4

2.2 Térmitas em florestas comerciais ...................................................... 6

2.3 Grupos funcionais de térmitas ..................................................... 9

2.4 Modificação do habitat natural: efeitos na comunidade de térmitas........ 11

2.4.1 Estudos no Brasil .................................................................. 11

2.4.2 Estudos em outros países...................................................... 13

2.5 Avaliando a diversidade de espécies .............................................. 16

2.6 Protocolo de amostragem .......................................................... 18

3 MATERIAL E MÉTODOS …......................................................... 21

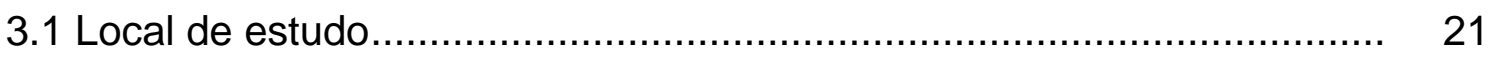

3.2 Caracterização dos ambientes...................................................... 23

3.3 Metodologia de amostragem..................................................... 28

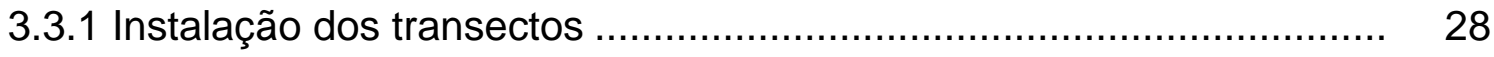

3.3.2 Tipos de amostragens ......................................................... 29

3.4 Georreferenciamento dos ambientes e transectos .......................... 32

3.5 Identificação dos térmitas ................................................................. 35

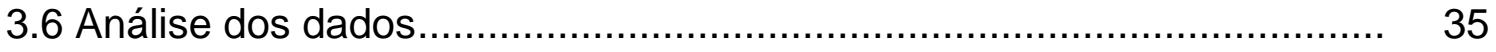

3.6.1 Análise estatística .............................................................. 35 


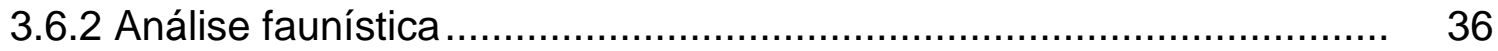

4 RESULTADOS E DISCUSSÃO .......................................................... 38

4.1 Riqueza total de espécies .............................................................. 38

4.2 Abundância relativa ................................................................... 41

4.2.1 Família Kalotermitidae .......................................................... 43

4.2.2 Família Rhinotermitidae ............................................................ 44

4.2.3 Família Termitidae ............................................................. 45

4.2.3.1 Subfamília Apicotermitinae .................................................. 45

4.2.3.2 Subfamlía Nasutitermitinae ................................................. 48

4.2.3.3 Subfamília Termitinae .............................................................. 51

4.3 Caracterização das comunidades................................................. 52

4.4 Comparação das comunidades .................................................... 59

4.5 Considerações finais .................................................................. 60

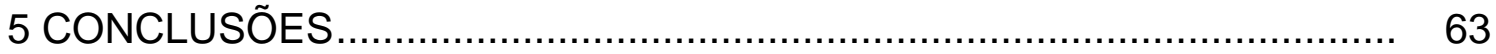

REFERÊNCIAS BIBLIOGRÁFICAS ...................................................... 65 


\title{
DIVERSIDADE DE TÉRMITAS EM CULTIVOS DE EUCALIPTO E FRAGMENTOS FLORESTAIS NA ESTAÇÃO EXPERIMENTAL DE CIÊNCIAS FLORESTAIS - ESALQ/USP, ANHEMBI, SP
}

\author{
Autora: LUCIANE KERN JUNQUEIRA \\ Orientador: Prof. Dr. EVONEO BERTI FILHO
}

\section{RESUMO}

Este trabalho objetivou descrever as comunidades de térmitas em sete ambientes florestais, que incluíram florestas de eucalipto de diferentes idades, um fragmento florestal, e ambientes em processo de sucessão inicial e avançada em Anhembi, SP. Por ambiente, foram identificados os grupos taxonômicos de térmitas, determinando a riqueza e a abundância relativa das espécies. Para tanto, em cada ambiente foi traçado um transecto de $100 \mathrm{~m} \times 5$ $\mathrm{m}$, dividido em dez setores intercalados cada um com $15 \mathrm{~m}^{2}$. Por setor, foram realizadas amostragens em serrapilheira, raízes e restos de madeira, em toras, sob galhos e troncos, em ninhos e demais micro-habitats, além de dez blocos de solo $\left(1.000 \mathrm{~cm}^{3}\right)$ e através de isca Termitrap ${ }^{\circledR}$. Os dados foram submetidos a análise de variância (ANOVA) e análise faunística onde foram calculados, pelo programa ANAFAU, o índice de diversidade de Shannon-Wiaver $\left(\mathrm{H}^{\prime}\right)$, o índice de abundância e o índice de eqüitabilidade. A similaridade entre as 
comunidades foi avaliada através da análise de Cluster. Foram obtidas 1.196 amostras de térmitas, distribuídas entre as famílias Kalotermitidae, Rhinotermitidae e Termitidae. A riqueza total foi de 17 espécies, variando de oito a treze por ambiente. Três morfo-espécies de Apicotermitinae, Heterotermes tenuis, Cornitermes sp., Diversitermes diversimiles e Embiratermes sp. apresentaram diferenças significativas quanto a abundância relativa entre os ambientes avaliados. As morfo-espécies de Apicotermitinae não tiveram sua riqueza e abundância reduzidas devido a implantação do eucalipto. Os calotermitídeos, Glyptotermes sp., Neotermes sp. e Rugitermes sp., mesmo com abundâncias relativas baixas, tiveram sua ocorrência vinculada a presença de madeira no solo. Os maiores índices de diversidade foram registrados para o fragmento florestal e o ambiente em processo de sucessão avançada, sugerindo que para os plantios de eucalipto o período mais crítico à redução da diversidade de térmitas seria o segundo ano da implantação da floresta. 


\section{DIVERSITY OF TERMITES IN EUCALYPT CROPS AND FOREST FRAGMENTS AT THE UNIVERSITY OF SÃO PAULO EXPERIMENTAL STATION OF FORESTRY SCIENCES IN ANHEMBI, STATE OF SÃO PAULO, BRAZIL}

Author: LUCIANE KERN JUNQUEIRA Adviser: Prof. Dr. EVONEO BERTI FILHO

\section{SUMMARY}

This paper describes the termite communities from seven forest environments, including different aged eucalypt forests, one forest fragment and areas of initial and advanced succession process, in Anhembi, State of São Paulo, Brazil. All the environments evaluated were identified for the taxonomic groups of termites and had their richness and relative abundance of termite species determined. For each environment one extended a transect $(100 \mathrm{~m} \times 5$ $\mathrm{m}$ ), divided into 10 sectors (15 square meters each) in-between. Samples were taken from litter, roots and wood remainings, logs, under branches and trunks, termite nests and other microhabitats, besides ten soil parcels (1,000 cubic centimeters each) and by using Termitrap ${ }^{\circledR}$ baits. The data were submitted to ANOVA and faunistic analysis using the ANAFAU program for calculating the diversity index of Shannon-Wiaver $\left(\mathrm{H}^{\prime}\right)$, and the abundance and equitability 
indexes. The similarity among the communities was evaluated through the Cluster analysis. There were obtained a total of 1,196 samplings of termites belonging to the families Kalotermitidae, Rhinotermitidae and Termitidae. The total richness was 17 species, ranging from 8 to 13 in the different environments. Three morphospecies of Apicotermitinae, Heterotermes tenuis, Cornitermes sp., Diversitermes diversimiles and Embiratermes sp. presented significant differences as to relative abundance among the evaluated environments. The richness and abundance of the Apicotermitinae morphospecies were not reduced due to the eucalypt introduction. The occurrence of the Kalotermitidae, Glyptotermes sp., Neotermes sp. and Rugitermes sp., although presenting relatively low abundance, was observed to be due to the presence of wood in the soil. The highest diversity indexes were registered for the forest fragment and the advanced succession process areas. This suggests that, regarding the plantation of eucalypts, the most critical period for the reduction of termite diversity would be the second year after eucalypt introduction. 


\section{INTRODUÇÃO}

As comunidades de térmitas constituem sistemas biológicos complexos, envolvendo uma diversidade de espécies que apresentam diferentes tipos de alimentação e de nidificação. Nos ecossistemas terrestres, estes insetos são os maiores responsáveis - não necessariamente o grupo dominante - pela decomposição e mineralização do carbono, influenciando as propriedades e a estrutura do solo (Bignell \& Eggleton, 2002). De acordo com Lavelle et al. (1997) os térmitas, juntamente com as minhocas, são os principais invertebrados envolvidos na ingestão e/ou manipulação de matéria orgânica e mineral.

A estrutura da vegetação afeta a diversidade dos térmitas através da quantidade e qualidade da serrapilheira disponibilizada. Assim, mudanças nesta estrutura, decorrentes de fragmentação, desmatamento, implantação de florestas comerciais, ou mesmo dos processos de regeneração e recomposição, podem alterar as comunidades de térmitas.

Em sistemas florestais, a atividade dos térmitas pode ser abordada de forma diferenciada. Em florestas naturais, eles são importantes componentes da fauna de solo, desempenhando papel essencial na decomposição da matéria orgânica, ciclagem de nutrientes, aeração e drenagem, bem como no estabelecimento de novos solos em áreas erodidas (Collins, 1981; Berti Filho, 1995). Entretanto, em florestas implantadas, podem estar entre as principais pragas, provocando perdas econômicas significativas na implantação dos cultivos. As espécies do gênero Eucalyptus são, particularmente, suscetíveis e 
muitas questões sobre esta problemática ainda permanecem sem resposta (Wardell, 1987).

Em florestas implantadas, a alteração da estrutura vegetacional provoca mudanças na disponibilidade de material vegetal e/ou alterações no nicho ecológico das espécies que, conseqüentemente, podem modificar a diversidade local de térmitas, favorecendo ou não algumas espécies. No primeiro caso, questiona-se se as espécies favorecidas seriam aquelas com potencial para tornarem-se pragas. No segundo, o desfavorecimento de espécies levaria à redução da diversidade. Porém, ambos os casos afetariam os processos de decomposição, ciclagem de nutrientes, a estrutura e as propriedades do solo local.

De acordo com Lavelle et al. (1997) alterações na comunidade vegetal, intensificação do uso do solo e alterações físicas da floresta podem reduzir a diversidade de térmitas atingindo especialmente os geófagos e, devido a alterações na disponibilidade de matéria orgânica, algumas espécies podem adquirir o status de praga. Para Mill (1982), o efeito mais óbvio do desmatamento é a redução no número de espécies que constroem ninhos arborícolas ou se alimentam de madeira viva. A remoção das árvores deixa a área desmatada temporariamente inabitável para algumas destas espécies e seus nichos ecológicos são ocupados por outras menos sensíveis, que podem se tornar pragas. Além disso, a alteração dos elementos microclimáticos não permite a manutenção de colônias de espécies de térmitas muito suscetíveis.

Constantino (1992) relatou que a Região Neotropical é a segunda maior em número de espécies de térmitas descritas, superada somente pela Região Etiópica. Entretanto, o trabalho na busca de dados no Neotrópico é limitado quando comparado às detalhadas coleções e estudos de térmitas de partes da África. Bignell \& Eggleton (2002) referem que há um volume considerável de publicações abordando a ecologia de térmitas na África, porém informações sobre florestas tropicais, onde os térmitas geófagos são dominantes, ainda são escassas, apesar de já incluírem alguns estudos na Malásia, Sabá e Sumatra. 
Na América do Sul, tanto a taxonomia quanto a ecologia de térmitas ainda estão em desenvolvimento. Os dados obtidos são para a floresta Amazônica, florestas alagadas e cerrado. Como muitos dos estudos na América do Sul baseiam-se na amostragem de ninhos, segundo aqueles autores, pode-se ter a impressão de que a fauna é dominada por espécies xilófagas mas que, provavelmente, seria apenas um artefato da sub-amostragem do solo.

Para o estado de São Paulo, não há dados sobre a fauna de térmitas em floresta primária, tampouco sobre como as alterações na estrutura vegetacional decorrentes das práticas silviculturais, interferem nas comunidades desses insetos. Neste estado, o cultivo de eucalipto destaca-se e, apesar das informações sobre as espécies de térmitas encontradas nesta cultura estarem sendo obtidas aos poucos - bem como o aprimoramento de metodologias de coleta - já fornecem dados valiosos (vide Junqueira \& Berti Filho, 2000). Entretanto, ainda não está claro se a presença de térmitas praga em eucalipto é decorrente ou não de mudanças das comunidades destes insetos devido às práticas silviculturais. Em caso positivo, o diagnóstico das áreas, identificando a riqueza e a abundância das espécies de térmitas, poderá fornecer subsídios para a adoção de um manejo da vegetação local durante o plantio e o cultivo do eucalipto. Jones et al. (2003) já recomendam um manejo em áreas agrosilviculturais que mitigue as perdas nas comunidades de térmitas, utilizando técnicas menos impactantes. Também recomendam a maximização do tamanho e a conexão dos fragmentos, reduzindo a extensão das bordas e permitindo que a madeira se decomponha in situ.

Tendo em vista as questões apresentadas acima, este trabalho objetivou descrever as comunidades de térmitas em sete ambientes florestais na Estação Experimental de Ciências Florestais da ESALQ/USP, em Anhembi, SP, quanto a seus grupos taxonômicos. Em cada ambiente objetivou-se determinar a riqueza e a abundância relativa das espécies de térmitas. Os dados obtidos foram utilizados para avaliar a similaridade entre os ambientes e buscar explicações para as possíveis diferenças encontradas. 


\section{REVISÃO DE LITERATURA}

\subsection{Considerações gerais sobre os térmitas}

Os térmitas pertencem a Ordem Isoptera e, assim como alguns Hymenoptera, são considerados insetos eussociais. Apresentam indivíduos da mesma espécie cuidando das formas jovens; divisão de trabalho reprodutiva, com indivíduos mais ou menos estéreis trabalhando em benefício dos férteis e sobreposição de pelo menos duas gerações, em estágios de desenvolvimento que possam contribuir para a sobrevivência da colônia (Wilson, 1980).

A Ordem Isoptera reúne sete famílias: Hodotermitidae, Kalotermitidae, Mastotermitidae, Rhinotermitidae, Serritermitidae, Termitidae e Termopsidae (Fontes \& Monteiro, 1998). Segundo Constantino (1999) e Constantino \& Schlemmermeyer (2000), no Brasil ocorrem quatro famílias: 1) Kalotermitidae, que reúne os térmitas xilófagos, que vivem em madeira seca, sem contato com o solo; o habitat natural da maioria das espécies é florestal, mas também ocorrem em vegetação aberta, como o cerrado, vinculado à presença de árvores e madeira. 2) Rhinotermitidae, com a maioria dos térmitas de hábitos subterrâneos, alimentando-se de madeira, alguns sendo pragas importantes. 3) Serritermitidae, com um único gênero e espécie conhecidos, restrito ao Brasil, ocorre na região dos cerrados e em algumas savanas amazônicas, como inquilina de ninhos de Cornitermes, aparentemente alimentando-se da matéria orgânica das paredes do ninho. 4) Termitidae, família bastante diversificada, incluindo os térmitas comedores de madeira, de folhas, húmus e líquens, bem como os cultivadores de fungo (estes últimos não ocorrem no Brasil). 
De acordo com Fontes (1995), o número de espécies registradas para o Brasil, em torno de 200, seguramente está subestimado, pois há espécies descritas que não foram registradas no país, bem como muitas que ainda não foram descritas. Para Constantino (1999), um dos principais obstáculos ao desenvolvimento da termitologia neotropical é a falta de um sólido trabalho taxonômico.

$\mathrm{Na}$ biologia de térmitas, os textos gerais mais destacados, com revisões detalhadas, são os de Grassé $(1949,1982,1984,1985)$ e os de Krishna \& Weesner $(1969,1970)$. Destacam-se também obras específicas, como as de Lee \& Wood (1971) e Mathews (1977), esta última resultante de um estudo dos térmitas de parte do Mato Grosso do Sul, com informações taxonômicas e biológicas sobre os grupos locais.

Na sistemática destaca-se a obra de Araújo (1977) - o Catálogo dos Isoptera do Novo Mundo - essencial ao trabalho de identificação. Além desta, obras como as de Fontes (1983, 1985); Mill (1983); Cancello $(1986,1989)$ e Constantino (1998, 1999), que incluem catálogos, chaves de identificação e revisões de gêneros, também constituem bibliografia fundamental para a identificação dos térmitas.

A sistemática de térmitas incorpora características morfológicas externas, morfologia do tubo digestivo do operário, padrão de arquitetura do ninho, características químicas da secreção defensiva dos soldados, particularidades comportamentais relacionadas com padrões morfológicos e hábitos. Assim, o estudo taxonômico não se restringe ao inseto morto, mas requer informações sobre a biologia geral do inseto. A presença de três castas, com grande variabilidade morfológica dificulta a sistemática, pois cada uma tem potencial taxonômico. Os alados, com grande semelhança entre espécies, são produzidos sazonalmente e, portanto, não são encontrados nas coletas realizadas fora do período de sua produção. Os soldados formam a casta mais importante para a taxonomia, embora muitas vezes apresentem polimorfismo ou estejam verdadeiramente ausentes, como no caso da maioria dos gêneros 
da subfamília Apicotermitinae. Os operários são muito semelhantes e caracteres taxonômicos são obtidos através do estudo do tubo digestivo. Finalmente, o ninho fornece um conjunto de caracteres sistemáticos, baseados principalmente no padrão arquitetural e nos materiais utilizados para a sua construção (Fontes, 1995).

\subsection{Térmitas em florestas comerciais}

Nas florestas que utilizam espécies exóticas em áreas tropicais, os térmitas têm provocado danos tão significativos, que são considerados um fator limitante para a implantação de florestas comerciais (Harris, 1971; Cowie et al., 1989).

Existem dois grupos de térmitas-praga em florestas de eucalipto. No primeiro estão aqueles que atacam mudas desde o plantio até um ano de idade, conhecidos como térmitas de mudas, raízes ou de solo: Ex.: Syntermes molestus, Syntermes insidians e Cornitermes cumulans, que ocasionam a destruição do sistema radicular ou o anelamento da muda na região do colo, danos que geralmente causam a morte da planta. Caso as condições do solo sejam favoráveis, as mudas podem resistir ao ataque, formando calos que irão originar um novo sistema radicular, acima do destruído, ou ainda emitir brotação para formar uma nova parte aérea nos casos de anelamento da região do colo. Em conseqüência, as árvores poderão ter sistema radicular deficiente e sustentação inadequada, ou serão árvores dominadas, devido ao atraso no desenvolvimento inicial. A mortalidade nestes casos é expressiva, ocasionando danos que, em mudas de Eucalyptus grandis no Brasil, chegam a $18 \%$, devido ao ataque de Cornitermes sp.. Para plantios comerciais, a porcentagem de falhas aceitável é de 2 a 5\%, pois acima deste nível o replantio torna-se oneroso (Wilcken, 1992; Wilcken \& Raetano, 1995).

No outro grupo estão os térmitas que atacam árvores de eucalipto com mais de dois anos, destruindo o seu interior, denominados térmitas do cerne: 
Ex: Coptotermes testaceus. Os térmitas penetram pela raiz, construindo galerias no interior do tronco, destruindo o cerne e deixando as árvores ocas, provocando uma queda na produtividade. Os danos internos só são evidenciados durante o corte ou a colheita, o que dificulta sua prevenção. No Quadro 1 é apresentada uma síntese das espécies de Eucalyptus hospedeiras de térmitas no Brasil e respectivos locais de dano (Wilcken \& Raetano, 1998).

Nair \& Varma (1985) sugerem que fatores tais como: espécies de térmitas presentes, densidade populacional, ritmo sazonal de atividade, acúmulo de serrapilheira e madeira, condições do solo, estado fisiológico da planta, idade e estado de estabelecimento, também estejam relacionados com a interação térmitas x eucalipto. Para Wardell (1987), a falta de programas de pesquisa para estudar as relações ecológicas entre térmitas, árvores hospedeiras e possíveis correlações com fatores edáficos, agrava esta situação.

O desmatamento e o isolamento também atuam diretamente na ecologia dos térmitas de florestas neotropicais. Como a maioria dos térmitas das florestas primárias é muito sensível a tais efeitos, não sobrevivendo a mudanças de habitat, as poucas espécies que conseguem adaptar-se podem se tornar importantes pragas na silvicultura (Mill, 1982).

Os dados disponíveis, apesar de poucos, sugerem que a retirada de madeira ou certas práticas agrícolas reduzem a riqueza dos térmitas e levam à perda seletiva de alguns grupos funcionais, principalmente dos geófagos (Wood et al., 1982). Porém, os efeitos das práticas silviculturais, consideradas menos drásticas, ainda são desconhecidos (Mill, 1982; Eggleton et al., 1995). 


\begin{tabular}{|l|c|c|c|}
\hline Espécie de térmita & Espécie de eucalipto & Local do dano & Referência \\
\hline Coptotermes testaceus & Eucalyptus sp. & Cerne & Nogueira \& Souza (1987) \\
\hline Coptotermes testaceus & E. grandis & Cerne & Santos et al. (1990) \\
\hline Heterotermes tenuis & E. grandis & Tronco (casca) & Raetano et al. (1997) \\
\hline Heterotermes tenuis & Eucalyptus spp. & Tronco & \\
Heterotermes sp. & Eucalyptus spp. & Tronco & \\
Anoplotermes pacificus & Eucalyptus spp. & Raízes & \\
Anoplotermes sp. & Eucalyptus spp. & Raízes & \\
Armitermes euamignathus & Eucalyptus spp. & Raízes & \\
Armitermes sp. & Eucalyptus spp. & Raízes & Mariconi (1981) \\
Neocapritermes opacus & Eucalyptus spp. & Raízes & Dietrich (1989) \\
Procornitermes araujoi & Eucalyptus spp. & Raízes & \\
Procornitermes striatus & Eucalyptus spp. & Raízes & \\
Procornitermes triacifer & Eucalyptus spp. & Raízes & \\
Cornitermes cumulans & Eucalyptus spp. & Raízes & \\
Cornitermes sp. & Eucalyptus spp. & Raízes & \\
\hline Cornitermes sp. & E. grandis & Raízes (mudas) & Wilcken (1992) \\
\hline Cornitermes sp. & E. citriodora & Raízes (mudas) & Papa \& Haro (1991) \\
\hline Cornitermes bequaerti & E. urophylla & Raízes e colo & Wilcken \& Raetano \\
Syntermes molestus & (mudas) & (1997) \\
\hline Syntermes insidians & Eucalyptus spp. & Raízes & Fonseca (1949) \\
Syntermes molestus & Eucalyptus spp. & Raízes & Dietrich (1989) \\
\hline Syntermes spp. & E. grandis & Raízes (mudas) & Alves et al. (1997) \\
\hline Cylindrotermes spp. & E. grandis e híbridos & Raízes (mudas) & \\
Embiratermes spp. & E. grandis e híbridos & Raízes (mudas) & \\
Obtusitermes spp. & Híbridos de Eucalyptus & Raízes (mudas) & \\
Rhynchotermes spp. & E. grandis & Raízes (mudas) & \\
Subulitermes spp. & E. grandis e híbridos & Raízes (mudas) & \\
\hline & & & \\
\hline
\end{tabular}

Quadro 1 - Relação das espécies de Eucalyptus hospedeiras de térmitas no Brasil e locais de dano (modificado de Wilcken \& Raetano, 1998) 


\subsection{Grupos funcionais de térmitas}

Por grupos funcionais, ou tróficos, entende-se o agrupamento das espécies de térmitas de acordo com os seus requerimentos específicos de dieta (Mathews, 1977; Gontijo \& Domingos, 1991; De Souza \& Brown, 1994; Eggleton et al., 1995; Eggleton et al., 1997; Jones \& Brendell, 1998; Jones, 2000). Bignell \& Eggleton (2002) referem que cinco grupos funcionais maiores podem ser assim reconhecidos:

- geófagos: térmitas que se alimentam de solo. Utilizam material bastante heterogêneo, com altas proporções de matéria orgânica e sílica e, diferentemente dos outros grupos, baixas proporções de tecido vegetal. São encontrados somente nas subfamílias Apicotermitinae, Nasutitermitinae e Termitinae.

- xilófagos: alimentam-se de madeira, que também pode estar na serrapilheira, incluindo ramos e galhos mortos que ainda estão nas árvores. A maioria dos térmitas inferiores alimenta-se de madeira e as espécies xilófagas ocorrem em todas as subfamílias de Termitidae, exceto em Apicotermitinae. Ocorre uma sucessão de espécies quanto ao uso do recurso, de acordo com seu estado de decomposição, decorrente da presença de fungos e do conteúdo de umidade.

- intermediários entre geófagos e xilófagos: alimentam-se de madeira extremamente decomposta, que já perdeu sua estrutura e tornou-se friável, semelhante ao solo, ou de solo que se encontra abaixo, na superfície ou no interior de toras em decomposição ou, ainda, em um

misto de serrapilheira e raízes superficiais. $\mathrm{Na}$ análise de comunidades, os térmitas que estão no grupo interface 
geofagia/xilofagia, são agrupados como geófagos. A categoria sobrepõe-se as duas categorias adjacentes, sendo encontrada somente nas subfamílias Apicotermitinae, Nasutitermitinae e Termitinae.

- forrageadores em serrapilheira: alimentam-se predominantemente das folhas da serrapilheira ou de pequenos pedaços de madeira, levandoos para o ninho e armazenando-os temporariamente. Ocorrem nas subfamílias Apicotermitinae, Macrotermitinae, Nasutitermitinae e Termitinae. Devido as numerosas galerias e/ou camadas de solo construídas sobre a madeira, serrapilheira e superfície do solo, são mais conspícuos do que os demais grupos funcionais.

- comedores de gramíneas: térmitas que forrageiam permanentemente em gramíneas e vegetação baixa, em geral já morta e seca, cortando e transportando o material cortado para o ninho. São encontrados nas subfamílias Hodotermitinae, Macrotermitinae, Nasutitermitinae e Termitinae.

- grupos menores de alimentação: são constituídos por alguns térmitas que se alimentam de fungos, algas ou líquens na superfície dos troncos de árvores. Outros são oportunistas, alimentando-se de estrume e cadáveres de vertebrados. Algumas espécies de térmitas também utilizam como item alimentar, obrigatório ou facultativo, os ninhos construídos por outras espécies.

Segundo Eggleton et al. (1998), as espécies de cada grupo funcional, de modo geral, apresentam um padrão de consumo similar. Entretanto, de acordo com Jones (2000), a classificação em grupos funcionais depara-se com a 
necessidade do conhecimento detalhado da ecologia nutricional dos térmitas, principalmente no caso dos geófagos.

Bignell \& Eggleton (2002) referem alguns trabalhos mostrando que, em condições desfavoráveis, algumas espécies podem se alimentar em mais de um grupo. A classificação apresentada também possui algumas desvantagens, pois não há distinção entre tecidos vivos e mortos de plantas. Em florestas, árvores vivas são atacadas por espécies de Coptotermes e pequenas raízes podem ser consumidas, aparentemente, pelos geófagos. Há exemplos também, como o da subfamília Macrotermitinae, de difícil caracterização, pois operários de diferentes idades alimentam-se de fungo simbiôntico, além de serrapilheira fresca ou estocada, incluindo solo, que também é encontrado no tubo digestivo.

Além dos grupos funcionais, Eggleton et al. (1996) sugerem a utilização de grupos taxonômicos para avaliar os efeitos do distúrbio florestal sobre a comunidade de térmitas, pois os térmitas que se alimentam de solo apresentarem diferenças morfológicas e anatômicas claras. Portanto, a composição taxonômica da comunidade também pode ser utilizada como um indicativo da função ecológica.

\subsection{Modificação do habitat natural: efeitos na comunidade de térmitas}

\subsubsection{Estudos no Brasil}

Na Amazônia Central, Bandeira (1979) estudou o efeito do desmatamento sobre as populações de térmitas, avaliando a distribuição e a diversidade destes insetos em áreas de floresta primária, capoeira e pastagem. A maioria dos gêneros apresentou distribuição equivalente nas três áreas. $O$ gênero Nasutitermes foi o mais comum e com maior diversidade, sendo mais freqüente em pastagem, onde também foi observado o maior número de ninhos. Os térmitas de solo foram encontrados em maior número na capoeira, seguido da pastagem e, por fim, da floresta. O autor sugeriu que a retirada da 
vegetação primária e as alterações microclimáticas decorrentes seriam responsáveis pela distribuição de alguns grupos de Isoptera.

Trabalhando em quatro locais próximos a Manaus, Mill (1982) encontrou maior densidade de térmitas em ilhas do que em terra firme, provavelmente devido à competição por alimento. Para o autor, os térmitas adaptados à vida em capoeira, ilhas e igapós, são espécies que podem se tornar pragas na silvicultura (ex.: Coptotermes e Nasutitermes). A fauna de térmitas em áreas de terra firme e várzea da Amazônia Brasileira foi distinta, com baixo índice de similaridade. A composição de espécies e a diversidade foram muito variáveis entre as localidades, sem correlação aparente com clima ou tipo de vegetação. Parte destas diferenças certamente ocorreu devido ao esforço de coleta e aos métodos de amostragem.

Constantino (1992), analisando a fauna de térmitas em florestas primárias de duas localidades da Amazônia Brasileira, verificou que os da subfamília Nasutitermitinae foram o grupo dominante tanto em número de espécies, quanto em abundância, em especial o gênero Nasutitermes. A maioria das espécies encontradas era xilófaga, muitas restritas à madeira em decomposição. Os humívoros foram o segundo grupo em número de espécies. A composição e a diversidade de espécies variaram entre os diferentes locais e, aparentemente, não apresentaram correlação com o clima ou o tipo de vegetação.

De Souza \& Brown (1994), em trabalho pioneiro, estudaram comunidades de térmitas na floresta Amazônica e em fragmentos de reservas isoladas vizinhas. Os geófagos predominaram na floresta, com maior riqueza de espécies e menor proporção de espécies raras. Já nos fragmentos predominaram os que utilizam a serrapilheira e os de hábito alimentar intermediário entre geofagia e xilofagia. Além disso, os térmitas utilizaram mais eqüitativamente os habitats na floresta do que nos fragmentos, sugerindo uma inadequabilidade de habitat crescente com a fragmentação e que a composição 
das comunidades de térmitas nos fragmentos seria resultado do padrão intrínseco da floresta e das perdas causadas pela fragmentação.

Bandeira et al. (2003), ao identificarem a termitofauna presente em seis ambientes com diferentes níveis de distúrbios localizados no Brejo dos Cavalos, $\mathrm{PE}$, constataram uma redução na diversidade de térmitas à medida que aumentaram os distúrbios, além de não encontrarem estes insetos em uma área de monocultura. Os térmitas que se alimentam de húmus foram mais afetados do que os de alimentação intermediária. Paralelamente, aqueles que se alimentam de madeira, apresentaram maior resiliência, enquanto algumas espécies, favorecidas em áreas de florestas secundárias, tenderam a desaparecer em áreas de agricultura que apresentavam pouca madeira disponível.

Sena et al. (2003) investigaram a fauna de térmitas em um fragmento de cerrado na Reserva Biológica de Guaribas, em Mamanguape, PB. A riqueza foi de 20 espécies, com a maioria das espécies sendo de térmitas xilófagos. Já a maior freqüência nos transectos de amostragem foi das espécies que se alimentam de húmus. A riqueza foi inferior à relatada para a vegetação de cerrado, provavelmente devido ao tempo de isolamento e distância do fragmento das grandes áreas de cerrado na região central do Brasil.

\subsubsection{Estudos em outros países}

Eggleton et al. (1995) avaliaram qualitativamente as comunidades de térmitas de cinco áreas com diferentes níveis de distúrbios florestais na Reserva Florestal de Mbalmayo, no sul da República de Camarões. Quando comparadas à floresta primária, as áreas com distúrbios severos apresentaram redução significativa na riqueza de espécies, enquanto que as áreas em processo de regeneração mostraram ligeiro aumento nesta riqueza. Os térmitas geófagos predominaram nas áreas em processo de regeneração e de floresta primária, porém sua riqueza foi reduzida nas áreas que sofreram distúrbios 
severos. Os xilófagos, por sua vez, pareceram mais resistentes aos distúrbios do que os geófagos, embora a riqueza de espécies tenha sido baixa nas áreas mais perturbadas.

$\mathrm{Na}$ mesma reserva florestal, Eggleton et al. (1996) avaliaram a diversidade, a abundância e a biomassa das comunidades de térmitas em cinco locais com diferentes níveis de distúrbio em dois anos sucessivos. A abundância e a biomassa foram altas no local cuja floresta era bastante semelhante à primária e na floresta em processo avançado de sucessão. Os distúrbios tiveram pouco efeito na abundância e na biomassa nas áreas de floresta, mas houve clara redução nestes componentes nas áreas abertas. Também foram encontradas diferenças na composição dos grupos taxonômicos, na abundância dos diferentes locais de nidificação e na composição dos grupos funcionais entre as áreas de estudo, esta última afetando principalmente os térmitas geófagos. A área semelhante à floresta primária apresentou uma comunidade de térmitas mais heterogênea quando comparada à áreas com mais distúrbios, possivelmente, decorrentes do maior número de micro-habitats disponíveis para os térmitas.

Davies et al. (1999) investigaram a resposta sucessional da comunidade de térmitas a perturbações experimentais em florestas na República de Camarões, avaliando as implicações para a restauração florestal. Mesmo nos tratamentos que envolveram distúrbios severos no solo e na cobertura de dossel, a riqueza e a abundância de térmitas foram recuperadas rapidamente quando madeira morta foi deixada no solo. Esta disponibilidade de madeira também resultou em ocupação por um grupo de térmitas diferente quanto à composição daqueles amostrados nos outros tratamentos, ressaltando que este grupo incluía tanto espécies xilófagas, quanto espécies geófagas.

Dibog et al. (1999) estudaram o impacto da cobertura vegetal nas comunidades de térmitas em sistemas agrosilviculturais de Terminalia ivorensis (Combretaceae), de seis e 18 anos no sul da República de Camarões, cujo subbosque foi utilizado para os cultivos de banana e cacau. No plantio de $T$. 
ivorensis com 18 anos, a maior abundância de térmitas ocorreu nos locais com dossel mais denso, independente do tipo de sub-bosque (banana ou cacau) e do sistema de cultivo (individual ou misto) bem como da forma de preparo do solo (conservando ou queimando a palha, neste caso somente para o cultivo de banana). Já no plantio de seis anos, não ocorreu diferença significativa na abundância de térmitas quando comparada à menor e à maior densidade do dossel, embora no último tenha ocorrido maior freqüência de térmitas. Por sua vez, o rendimento da colheita não estava diretamente relacionado à abundância das populações de térmitas, mas o rendimento na produção de cacau estava positivamente relacionado com a abundância dos térmitas geófagos (a maioria da comunidade), provavelmente decorrente das melhores condições do solo resultantes da presença deste grupo. Do total de 82 espécies de térmitas encontradas, 67 eram geófagas.

Jones et al. (2003) avaliaram o impacto da intensificação de uso do solo nas comunidades de térmitas em floresta tropical úmida na Província de Jombi em Sumatra, Indonésia. Para tanto, foi identificada a composição das comunidades em um gradiente de sete ambientes com distúrbios, que incluíram desde floresta primária, passando por diferentes sistemas silviculturais, até áreas com plantios de mandioca. Nos sete ambientes foram coletadas 54 espécies, sendo que a floresta primária apresentou a maior riqueza de térmitas, com 34 espécies, e o plantio de mandioca a menor riqueza, com apenas uma espécie de térmita. A abundância relativa dos térmitas geófagos, apresentou maior declínio ao longo do gradiente, em relação aos xilófagos. Foi constatado que a área basal das árvores está fortemente correlacionada com a riqueza e a abundância relativa dos térmitas, refletindo, portanto, a resposta adaptativa destes insetos à simplificação progressiva da estrutura física do habitat, resultante da menor cobertura do dossel, de alterações microclimáticas e da redução dos locais para alimentação e para nidificação. Os autores também analisaram estudos de outros pesquisadores onde todas, ou grande parte das comunidades foram avaliadas ao longo de um gradiente local de distúrbios, 
indicando de forma geral uma tendência ao declínio de riqueza e abundância das espécies com o aumento do uso do solo. Esta tendência é mais aparente quando se examinam gradientes mais distintos, que vão desde floresta primária até locais sem árvores.

Lavelle et al. (1997) referem os invertebrados de solo como "engenheiros dos ecossistemas de solo" uma vez que ingerem ou manipulam material orgânico e mineral, formando microestruturas. Citam as minhocas e os térmitas como os mais importantes engenheiros dos ecossistemas terrestres, pois, como mediadores da transformação dos nutrientes, exercem influência na diversidade e atividade da biota e dos níveis tróficos subordinados. Também consideram a hipótese de que a vegetação afeta tanto a abundância quanto a diversidade destes organismos através da qualidade e quantidade de serrapilheira, dentre outros efeitos. Mudanças nas comunidades vegetais afetariam, portanto, os engenheiros de solo.

O uso da terra e os distúrbios florestais, segundo Lavelle et al. (1997) são responsáveis pelas mudanças mais imediatas nos grupos funcionais das comunidades daqueles engenheiros. Os distúrbios afetam os térmitas através da redução da diversidade, especialmente daqueles que se alimentam de solo, e algumas espécies podem se tornar pragas devido as mudanças na disponibilidade de matéria orgânica. A redução na abundância dos engenheiros provoca decréscimo nos estoques de carbono no solo e desigualdade entre os grupos funcionais (compactantes $\mathrm{x}$ descompactantes), também pode resultar em degradação física do solo.

\subsection{Avaliando a diversidade de espécies}

A diversidade de espécies apresenta dois componentes. O primeiro é a riqueza, que corresponde ao número total de espécies presentes e, quando a finalidade é comparação, pode ser expressa como uma razão de espécies/área ou de espécies/número de indivíduos. O segundo é a abundância, que indica a 
eqüitabilidade (ou uniformidade) na distribuição do número de indivíduos entre as diferentes espécies (Odum, 1988).

Para Magurran (1988) as avaliações sobre diversidade de espécies freqüentemente estão restritas à riqueza de espécies, obtida através da contagem direta do número de espécies, porém sem relacionar com a abundância relativa de cada uma, o que é uma deficiência pois não existem comunidades onde as espécies apresentem a mesma abundância.

De acordo com Ricklefs (1996), as diferenças na abundância de espécies nas comunidades ocasionam dois problemas. Primeiro, o número total de espécies incluídas varia de acordo com o tamanho da amostra, isto é, quanto mais indivíduos são amostrados, maior será a probabilidade de serem encontradas espécies raras. Portanto, não é possível comparar a diversidade entre áreas amostradas com diferentes intensidades utilizando apenas a contagem do número de espécies. Segundo, as espécies não contribuem igualmente para a estimativa da diversidade total, uma vez que seus papéis funcionais na comunidade variam, em algum grau, de acordo com a sua abundância total. Para resolver os problemas abordados, tem-se utilizado os índices de diversidade, que avaliam também as proporções das espécies (abundância relativa) na amostra total de indivíduos.

Os quatro índices mais utilizados são: o índice de riqueza, o índice de eqüitabilidade (ou uniformidade) e os índices gerais de Simpson e de Shannon Wiaver, que combinam os dois componentes da diversidade. O índice de Simpson atribui um peso maior às espécies comuns e o de Shannon às espécies raras. Este último, não separa os componentes da diversidade, além de ser relativamente independente do tamanho da amostra (Odum, 1988, Begon et al., 1990).

O termo diversidade alfa $(\alpha)$ é usado para designar a diversidade referente a pequenas áreas de habitat ou de uma comunidade mais ou menos uniforme, portanto sensível à definição de habitat, à área e à intensidade de amostragem. Por sua vez, diversidade beta $(\beta)$ designa a diversidade entre 
habitats e, finalmente, a diversidade gama $(\gamma)$ relaciona-se à diversidade de uma grande área regional, bioma, ilha, continente, etc. (Odum, 1988; Ricklefs, 1996).

A diversidade beta é essencialmente uma medida que indica o quão diferentes (ou similares) são os habitats ou amostragens em relação a sua variedade e, algumas vezes, em relação a sua abundância. Para medir a diversidade beta entre dois locais são utilizados coeficientes de similaridade, os mais utilizados sendo o índice de Jaccard e o índice de Sorenson. Entretanto, quando há um número maior de locais para investigação, a diversidade beta é melhor representada através da análise de Cluster, que inicia a matriz fornecendo a similaridade entre cada par de locais. Os dois locais mais similares são então combinados, formando um grupo único, e a análise prossegue pelo agrupamento sucessivo de locais similares até que todos sejam combinados em um único dendograma. A análise de Cluster pode ser realizada tanto de forma qualitativa, considerando-se a presença ou ausência de espécies, quanto de forma quantitativa, utilizando-se dados referentes à abundância das espécies (Magurran, 1988).

\subsection{Protocolo de amostragem}

Ao medir diversidade, um dos problemas encontrados é conhecer o tamanho da amostra a ser adotada, o que muitas vezes é decidido de forma pragmática ou intuitiva. Entretanto, a intensidade de amostragem afeta a riqueza de espécies, tornando-se essencial que o mesmo tamanho de amostra seja utilizado em todos os locais de investigação (Magurran, 1988). De acordo com Odum (1988), há uma tendência ao aumento do número de espécies com o aumento da área, assim, relações espécies-área têm sido utilizadas para determinar o tamanho ótimo de amostras, bem como para predizer o número de espécies em áreas maiores do que a amostrada. 
Para Ricklefs (1996) estimativas de número de espécies são dificultadas pelo fato deste número aumentar em proporção direta ao número de indivíduos amostrados. A padronização nas medidas de diversidade com finalidade de comparação só é possível se as amostras forem comparáveis.

De acordo com Agosti \& Alonso (2000) a utilização de métodos de amostragem padronizados, para medir e monitorar a diversidade de formigas, possibilita a repetição de estudos em diferentes habitats, épocas do ano e por diferentes pesquisadores. Ao utilizar a mesma metodologia, torna-se possível comparar pesquisas individuais e inserí-las em um contexto global.

Comparações faunísticas de térmitas são significativas se baseadas em dados quantitativos, os quais são escassos. Entretanto, mesmo estes dados serão de pouca utilidade, se o esforço de amostragem e as técnicas de coleta forem diferentes. Devido à distribuição agregada e tipos de habitat, os térmitas têm sido tratados inadequadamente quanto à metodologia de coleta, dificultando a observação e a experimentação (Constantino, 1992; Martius, 1994). Assim, estes insetos, por serem importantes mediadores dos processos de decomposição dos ecossistemas tropicais, além de pragas expressivas em sistemas agrosilviculturais, necessitam de um padrão de amostragem que mostre, acuradamente, a composição local de espécies.

A grande dificuldade na amostragem de térmitas residia em dois fatores. Primeiro, a falta de uma padronização nas técnicas de coleta e, segundo, a ausência de uma técnica que refletisse, de forma segura, o número de espécies da área e que determinasse também o tamanho ótimo da amostra. Soma-se a isto o fato de que para os térmitas, como insetos sociais, a abundância não pode ser expressa pela contagem dos indivíduos e sim, pelo número de encontros com a espécie (Jones, 2000).

Recentemente foi desenvolvido e testado por Jones (2000) e Jones \& Eggleton (2000) um sistema de amostragem consistindo de um transecto dividido em setores percorridos por coletores especialmente treinados para avaliarem micro-habitats de térmitas até $2,0 \mathrm{~m}$ acima do solo. $\mathrm{O}$ transecto foi 
instalado em áreas com a fauna de térmitas previamente conhecida e documentada, sendo portanto possível avaliar sua eficiência quanto a representatividade da fauna local. Os resultados obtidos indicaram que 0 transecto dividido em setores é um método rápido e eficaz para o estudo das comunidades de térmitas. O protocolo descrito já é utilizado e tem resultado em amostragens representativas da composição taxonômica e funcional dos agrupamentos de térmitas locais.

A coleta em setores também fornece uma medida semiquantitativa da abundância relativa (número de encontros com cada espécie no transecto). Como este método padroniza o esforço de captura ou de coleta da área, ele pode ser utilizado para comparar a riqueza (número de espécies) e a abundância relativa de espécies entre áreas, porém não fornece medidas da abundância absoluta (número de indivíduos) por área, o que na realidade não tem significado no caso dos insetos sociais. O uso dos transectos divididos em setores para coleta pode ser considerado como um método relativamente rápido, simples, confiável e de custo acessível, para amostragens em florestas (Jones, 2000). 


\section{MATERIAL E MÉTODOS}

\subsection{Local de estudo}

A pesquisa foi conduzida na Estação Experimental de Ciências Florestais de Anhembi, pertencente à Universidade de São Paulo e sob administração do Departamento de Ciências Florestais da Escola Superior de Agricultura "Luiz de Queiroz" (ESALQ). A Estação localiza-se no município de Anhembi - SP

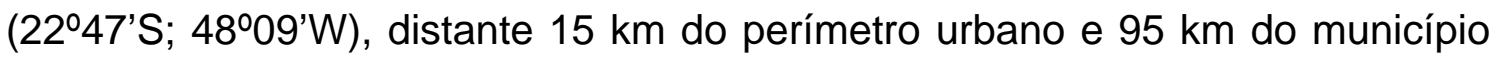
de Piracicaba e destina-se exclusivamente ao desenvolvimento de estudos com espécies florestais, nativas ou exóticas. Abrange uma área de aproximadamente 500 ha, à margem esquerda da represa do rio Tietê, remanescente das terras desapropriadas pelas Centrais Elétricas de São Paulo (CESP).

O clima local caracteriza-se como CA, subtropical úmido, com verões quentes e chuvosos e invernos moderadamente frios e secos, raramente ocorrendo geadas. A temperatura média do mês mais frio é de $17,0^{\circ} \mathrm{C}$ e a do mais quente $23,7^{\circ} \mathrm{C}$. A precipitação média anual é de cerca de $1.350 \mathrm{~mm}$, com déficit anual de $20 \mathrm{~mm}$. Com relevo plano a suave ondulado, apresenta solo arenoso com perfil profundo e permeável à água.

As amostragens de térmitas foram conduzidas em sete ambientes da Estação Experimental (Figura 1), no período de 21/01/2002 a 12/5/2003. 


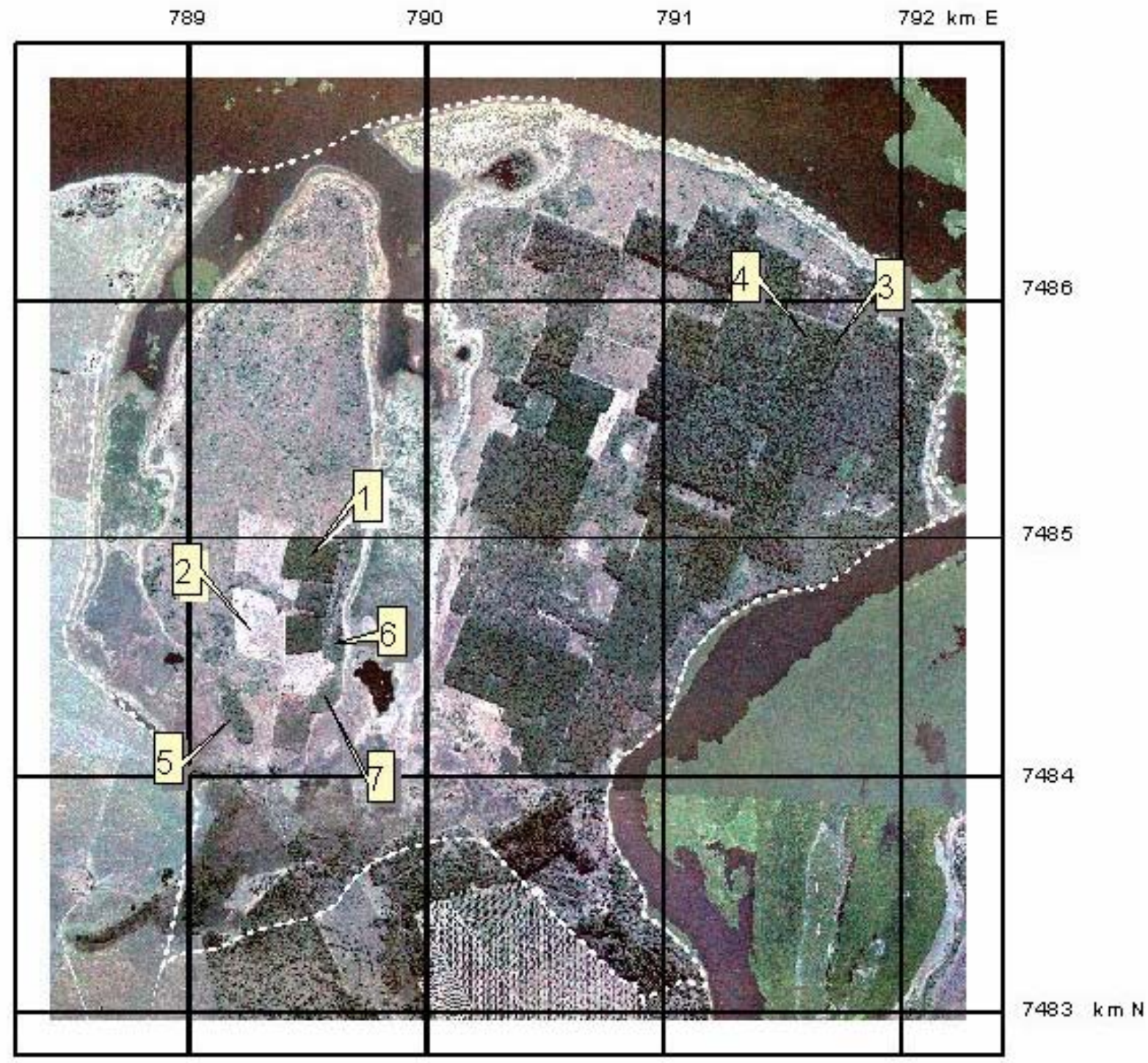

\section{Escala 1: 30.000}

Projeçã̃o UTM - Fuso 22

Figura 1 - Fotografia aérea digitalizada da Estação Experimental de Ciências Florestais, Anhembi, SP, obtida pela BASE aerofotogrametria, evidenciando os sete ambientes de amostragem 


\section{2- Caracterização dos ambientes}

O levantamento dos térmitas foi realizado em sete ambientes da Estação Experimental de Ciências Florestais de Anhembi, cujo código e descrição síntese encontram-se no Quadro 2.

\begin{tabular}{|c|c|c|c|c|}
\hline Código & Ambiente & Data & $\begin{array}{l}\text { Preparo } \\
\text { do solo }\end{array}$ & $\begin{array}{c}\text { Manejo } \\
\text { silvicultural }\end{array}$ \\
\hline A1 & $\begin{array}{l}\text { floresta implantada de } \\
\text { Eucalyptus grandis sem sub-bosque }\end{array}$ & $\begin{array}{l}\text { plantio setembro } \\
2001 \\
\end{array}$ & $\begin{array}{l}\text { gradagem } \\
\text { sulcamento }\end{array}$ & $\begin{array}{l}\text { coroamento c/ enxada } \\
\text { roçada mecânica }\end{array}$ \\
\hline A2 & $\begin{array}{l}\text { floresta implantada de } \\
\text { Eucalyptus urophylla sem sub-bosque }\end{array}$ & $\begin{array}{l}\text { plantio março } \\
2000\end{array}$ & $\begin{array}{c}\text { aração } \\
\text { gradagem } \\
\text { sulcamento }\end{array}$ & $\begin{array}{l}\text { capina manual } \\
\text { gradagem } \\
\text { rolo-faca }\end{array}$ \\
\hline A3 & $\begin{array}{l}\text { floresta implantada de } \\
\text { Eucalyptus urophylla com sub-bosque }\end{array}$ & $\begin{array}{l}\text { plantio agosto } \\
1991\end{array}$ & $\begin{array}{c}\text { aração } \\
\text { gradagem } \\
\text { sulcamento }\end{array}$ & $\begin{array}{l}\text { capina manual } \\
\text { gradagem } \\
\text { roçada mecânica }\end{array}$ \\
\hline A4 & $\begin{array}{l}\text { floresta implantada de } \\
\text { Eucalyptus urophylla sem sub-bosque }\end{array}$ & $\begin{array}{l}\text { plantio agosto } \\
1991\end{array}$ & $\begin{array}{c}\text { aração } \\
\text { gradagem } \\
\text { sulcamento }\end{array}$ & $\begin{array}{l}\text { capina manual } \\
\text { gradagem } \\
\text { roçada mecânica }\end{array}$ \\
\hline A5 & fragmento florestal & $\begin{array}{c}\text { exploração } \\
\text { seletiva até } 1976 \\
\end{array}$ & - & - \\
\hline A6 & $\begin{array}{l}\text { ambiente em processo de sucessão } \\
\text { recente }\end{array}$ & $\begin{array}{l}\text { recomposição em } \\
\text { novembro } 1993\end{array}$ & - & - \\
\hline A7 & $\begin{array}{l}\text { ambiente em processo de sucessão } \\
\text { avançada }\end{array}$ & $\begin{array}{c}\text { desbaste seletivo } \\
\text { até } 1986\end{array}$ & - & - \\
\hline
\end{tabular}

Quadro 2 - Códigos e síntese da descrição dos ambientes utilizados para o levantamento da termitofauna

Os ambientes foram caracterizados de acordo com as informações fornecidas pela equipe responsável da Estação Experimental, com exceção dos ambientes A5, A6 e A7 que foram descritos, quanto a composição da flora, pela Engenheira Florestal Eliza Harumi Takashiba. São eles:

- ambiente A1: Plantio de E. grandis em setembro de 2001 para teste de progênie, com espaçamento $3,0 \mathrm{~m} \times 2,0 \mathrm{~m}$. O preparo do solo foi através de gradagem e sulcamento e a manutenção silvicultural através de 
coroamento com enxada e roçada mecânica periódica. Possui 214,70 m de comprimento, 176,42 m de largura e área total de 3,77 ha (Figura 2).

- ambiente A2: Plantio de E. urophylla em março de 2000 destinado ao manejo de toras, com espaçamento 3,0 m x 2,0 m. O preparo do solo foi através de aração, gradagem e sulcamento e a manutenção silvicultural através de capina manual na linha de plantio e gradagem nas entrelinhas até um ano de idade. Foi utilizado rolo-faca periodicamente. Possui $266,86 \mathrm{~m}$ de comprimento, 224,15 m de largura e área total de 5,62 ha (Figura 2).

- ambiente A3: Plantio de E. urophylla em agosto de 1991 com espaçamento 3,0 $\mathrm{m} \times 2,0 \mathrm{~m}$. O preparo do solo foi através de aração, gradagem, sulcamento e a manutenção silvicultural através de capina manual na linha do plantio e gradagem nas entrelinhas até um ano. Neste ambiente houve sombreamento devido a regeneração do subbosque. Possui 422,12 m de comprimento, 212,83 m de largura e área total de 9,20 ha (Figura 2).

- ambiente A4: Localizado no mesmo talhão do ambiente A3, porém em local sem sub-bosque. Plantio de E. urophylla em agosto de 1991, com espaçamento 3,0 $\mathrm{m} \times 2,0 \mathrm{~m}$. O preparo do solo foi através de aração, gradagem, sulcamento e a manutenção silvicultural através de capina manual na linha do plantio e gradagem nas entrelinhas até um ano. Foi realizada roçada mecânica nas entrelinhas periodicamente. Com 422,12 m de comprimento e 212,83 m de largura, possui uma área total de 9,20 ha (Figura 2). 

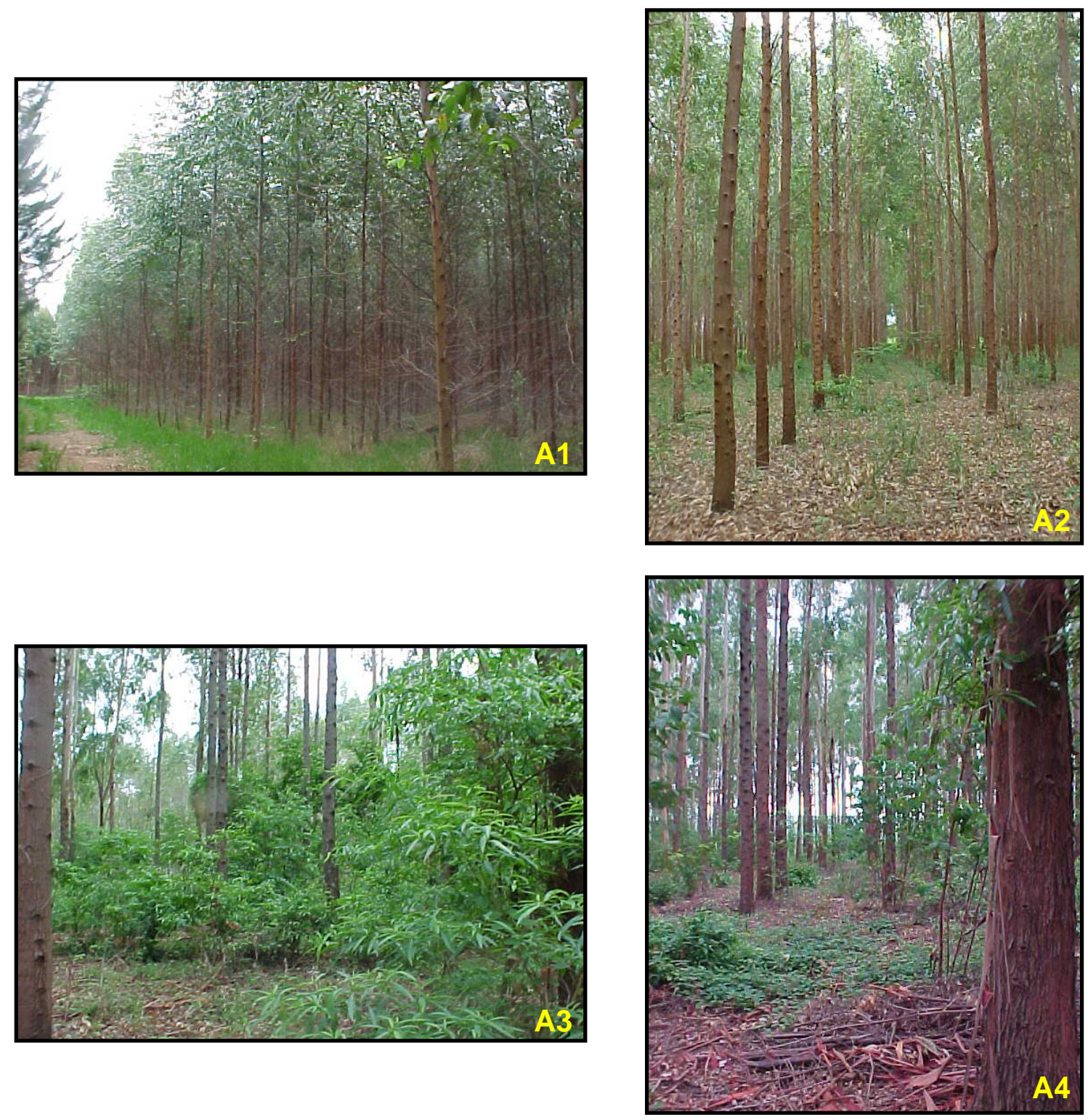

Figura 2 - Panoramas dos ambientes A1 a A4 em novembro de 2003: A1- vista parcial externa do talhão; A2- vista parcial interna do plantio; A3vista parcial interna do plantio, evidenciando os eucaliptos e o subbosque (após desbaste e com o sub-bosque já parcialmente limpo devido ao término das amostragens); A4- vista parcial interna do plantio (após desbaste e com o sub-bosque já regenerando devido ao término das amostragens) 
- ambiente A5: Fragmento florestal, com área de 1,82 ha $(254,45 \mathrm{~m}$ de comprimento e 100,57 m de largura), sofreu exploração seletiva de madeira e, a partir de 1976, deu-se início a preservação do local. A cobertura florestal é caracterizada por apresentar um dossel irregular com presença de árvores emergentes de até $15 \mathrm{~m}$ de altura. No estrato superior observou-se a presença de figueira (Ficus guaranitica), jacarandá paulista (Machaerium villosum), cedro (Cedrela fissilis), peroba (Aspidosperma polyneuron), jatobá (Hymenaea courbaril), copaíba (Copaifera langsdorffii), araribá (Centrolobium tomentosum), jequitibá branco (Cariniana estrellensis), cambará (Vernonia polyanthes), leiteiro (Tabernaemontana catharinensis), entre outras. Na condição de subbosque observou-se presença de serrapilheira depositada e recrutamento em algumas áreas de clareiras (Figura 3).
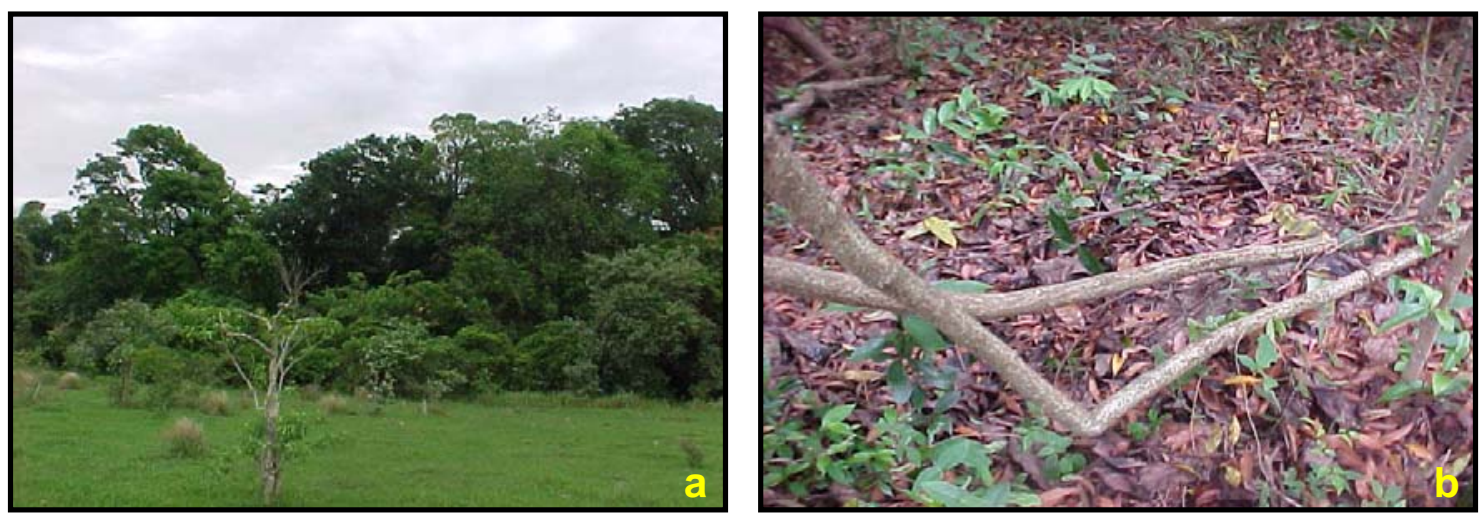

Figura 3 - Diferentes panoramas do ambiente A5 evidenciando em a) vista parcial externa e b) depósito de serrapilheira e recrutamento do banco de sementes em área de clareira 
- ambiente A6: Fragmento florestal de 1,2 ha (comprimento 174,55 m e largura 92,16 m) teve sua regeneração natural retirada e, desde 1993, faz parte de um projeto de recomposição da mata ciliar, quando foram plantadas algumas espécies nativas em espaçamento de 2,0 m x 3,0 m. Encontra-se em estágio de sucessão recente, em condições de muita luminosidade e com presença de gramíneas por toda a área. Observouse a ocorrência predominante de leiteiro ( $T$. catharinensis) e cambará ( $V$. polyanthes) no sub-bosque (Figura 4).

- ambiente A7: Fragmento florestal de 1,2 ha (comprimento 183,51 m e largura 85,77 m), é sobra de um desbaste seletivo realizado em 1986 para instalação de um plantio. Abandonado no mesmo período, está desde então em processo de regeneração natural. É caracterizado pela ausência de dossel definido e por apresentar-se muito perturbado devido ao pisoteio de gado. A cobertura florestal do ambiente apresenta espécies dos estágios iniciais da sucessão e alguns indivíduos remanescentes de figueiras ( $F$. guaranitica) com presença de lianas. Foram observadas espécies como embaúba (Cecropia spp.), fumo bravo (Solanum erianthum e Solanum granuloso leprosum), unha de vaca de espinho (Bauhinia forficata), açoita-cavalo (Luehea divaricata), urtigão (Urera baccifera), leiteiro ( $T$. catharinensis), cambará (V. polyanthes), entre outras. $\mathrm{Na}$ condição de sub-bosque observou-se uma alta ocorrência de recrutamento em todo o ambiente, decorrente da luminosidade e da presença de banco de sementes nestas clareiras (Figura 4). 

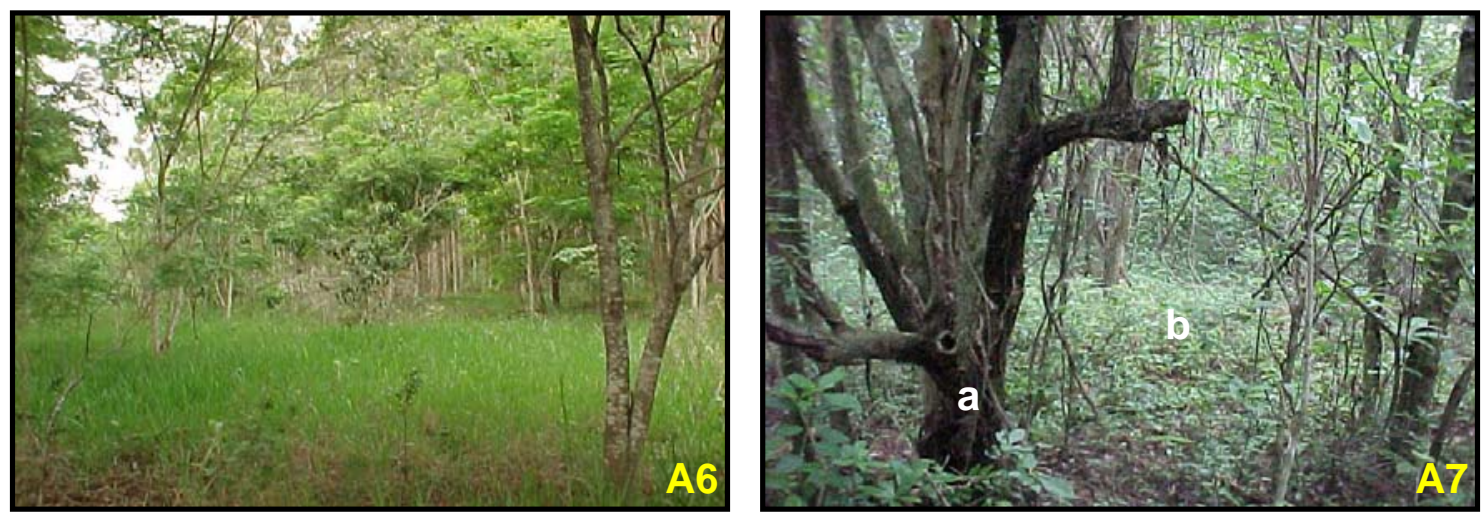

Figura 4 - Vista parcial do ambiente A6 e vista parcial interna do ambiente A7, evidenciando em a) indivíduo remanescente de Ficus guaranitica e em b) área de clareira com recrutamento do banco de sementes

\subsection{Metodologia de amostragem}

No decorrer de 16 meses, os ambientes foram amostrados quatro vezes, cada período de quatro meses correspondendo a uma repetição. As amostragens foram conduzidas adaptando a metodologia de transectos descrita por Jones \& Eggleton (2000).

\subsubsection{Instalação dos transectos}

Em cada ambiente foi traçado um transecto através da instalação de uma corda de $100 \mathrm{~m}$, amarrada nas extremidades por estacas, que permaneceu no mesmo local durante todo o período de amostragem. O transecto foi instalado, sempre que possível, no centro de cada ambiente (Figura 5). 


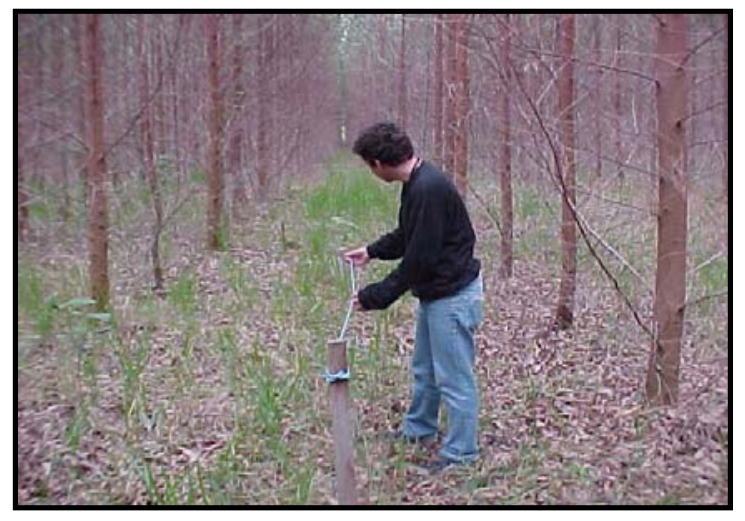

Figura 5 - Instalação do transecto em um dos ambientes amostrados

O transecto foi dividido em dez setores intercalados de $5 \mathrm{~m}$ de comprimento $\times 3 \mathrm{~m}$ de largura numerados seqüencialmente (Figura 6). Nos setores pares, os $3 \mathrm{~m}$ de largura foram considerados à esquerda e, nos setores ímpares, à direita do transecto.

\subsubsection{Tipos de amostragens}

Em cada setor do transecto foram realizadas três tipos de amostragens (vide Quadro 3) que, por serem distintas, objetivaram evitar que algumas espécies de térmitas, com hábitos diferenciados de alimentação e/ou de nidificação fossem excluídas devido a um artifício metodológico. Assim, as três formas de amostragem complementaram-se para uma avaliação mais apurada da termitofauna local. Entretanto, como todas as amostragens foram exclusivamente diurnas, é possível que algumas espécies de térmitas de hábitos noturnos estejam subamostradas. As amostragem foram através de: 
a) coleta manual: uma equipe treinada avaliou os diversos microhabitats onde são encontrados térmitas, que incluíam a serrapilheira e o húmus acumulados na base das árvores, entre raízes e restos de madeiras; no interior e sob toras, no solo, nos tocos de árvores, ramos e galhos; ninhos subterrâneos de térmitas e murundus e os ninhos arborícolas de térmitas até $2 \mathrm{~m}$ acima do nível do solo. $\mathrm{O}$ esforço de amostragem, isto é, o tempo em que o coletor permaneceu em cada setor procurando térmitas foi padronizado em uma hora;

b) blocos de solo: por setor foram retirados, ao acaso, dez blocos de solo $(10 \mathrm{~cm} \times 10 \mathrm{~cm} \times 10 \mathrm{~cm})$;

c) iscas Termitrap ${ }^{\circledR}$ : no centro de cada setor foi enterrada uma isca de papelão corrugado (15 cm de altura x $5 \mathrm{~cm}$ de diâmetro) a $15 \mathrm{~cm}$ de profundidade, 60 dias antes da coleta, totalizando dez iscas por transecto. 


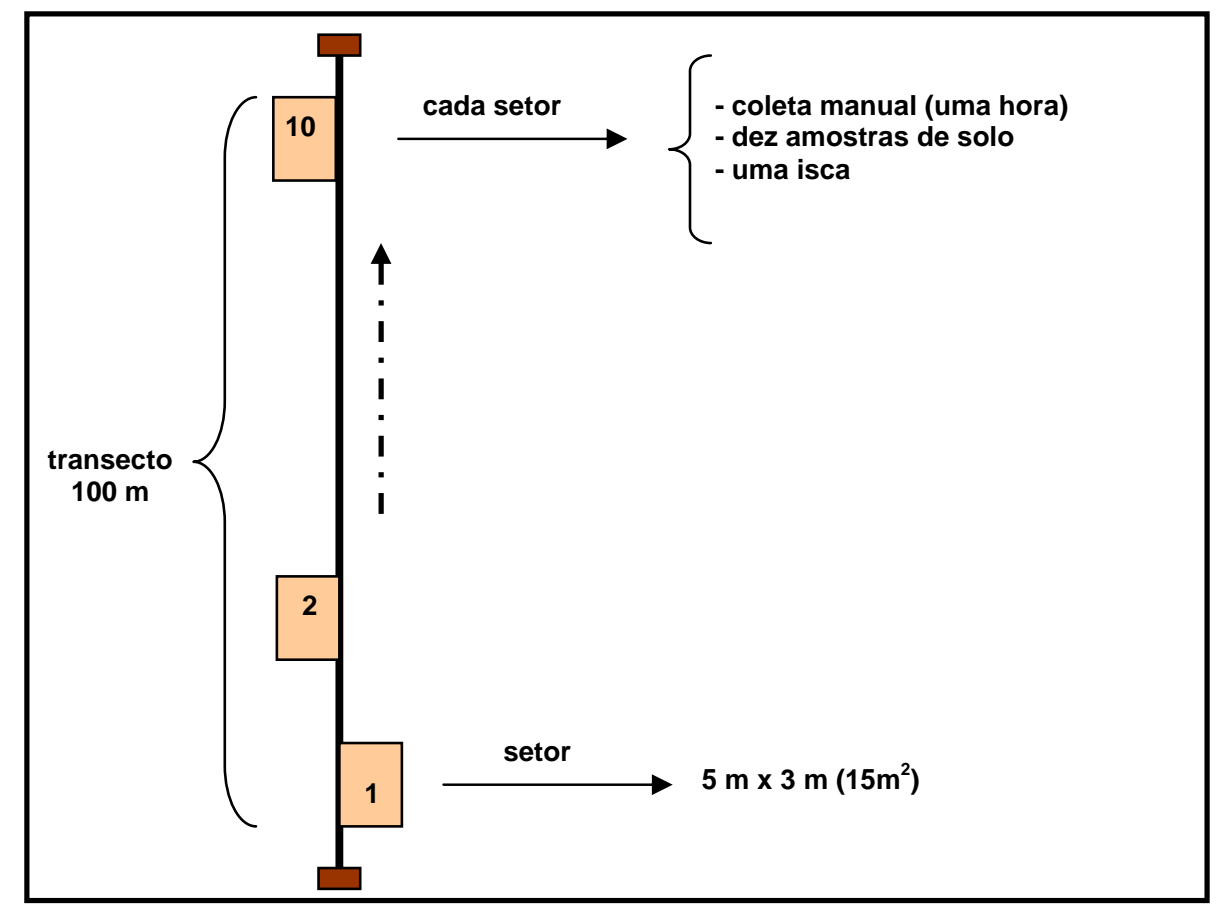

Figura 6 - Esquema do transecto, setores e tipo de amostragem nos setores

Todas as amostras obtidas foram acondicionadas em sacos plásticos individuais, contendo a data, o código do ambiente, o setor e o tipo de amostragem (coleta manual, solo ou isca) e levadas para laboratório para triagem.

Para a triagem, o conteúdo de cada saco plástico foi espalhado em bandeja de plástico branca. Com o auxílio do pincel, os térmitas foram transferidos para vidros etiquetados, contendo álcool 80\%, para posterior identificação, com todas as informações, referentes a coleta, preenchidas na planilha correspondente ao número. 


\begin{tabular}{|l|c|c|c|c|c|}
\hline \multirow{2}{*}{$\begin{array}{l}\text { Tipo de } \\
\text { amostragem }\end{array}$} & Setor & Transecto & Ambiente & Repetições & Geral \\
\cline { 2 - 6 } & 1 hora & 10 horas & 70 horas & 4 & 280 horas \\
\hline $\begin{array}{l}\text { Coleta manual } \\
\text { (horas) }\end{array}$ & 10 & 100 & 700 & 4 & 2.800 \\
\hline $\begin{array}{l}\text { Blocos de solo } \\
(10 \times 10 \times 10 \mathrm{~cm})\end{array}$ & 1 & 10 & 70 & 4 & 280 \\
\hline Iscas & & & & & \\
\hline
\end{tabular}

Quadro 3 - Total de amostragens por tipo de coleta

\subsection{Georreferenciamento dos ambientes e transectos}

Foram obtidas as coordenadas de pontos nos sete ambientes e respectivos transectos. bem como dos pontos de controle, como cruzamentos de estradas, cantos de talhões e da sede da estação para posterior georreferenciamento das imagens (Figuras 7 e 8). Uma vez conhecidos os posicionamentos de todos os ambientes e transectos, foi possível a extração de dados das imagens, incluindo o contorno de seus limites, minimizando a contaminação de bordadura. Foi utilizado um receptor de sinais GPS ("Global Positional System"), da marca GARMIN, modelo 295 MAP, que permite uma precisão de até três metros. Estes pontos foram escolhidos no mapa planimétrico da estação, consistindo em pontos estáveis ao longo do tempo, visíveis nas imagens e de fácil localização em campo. 


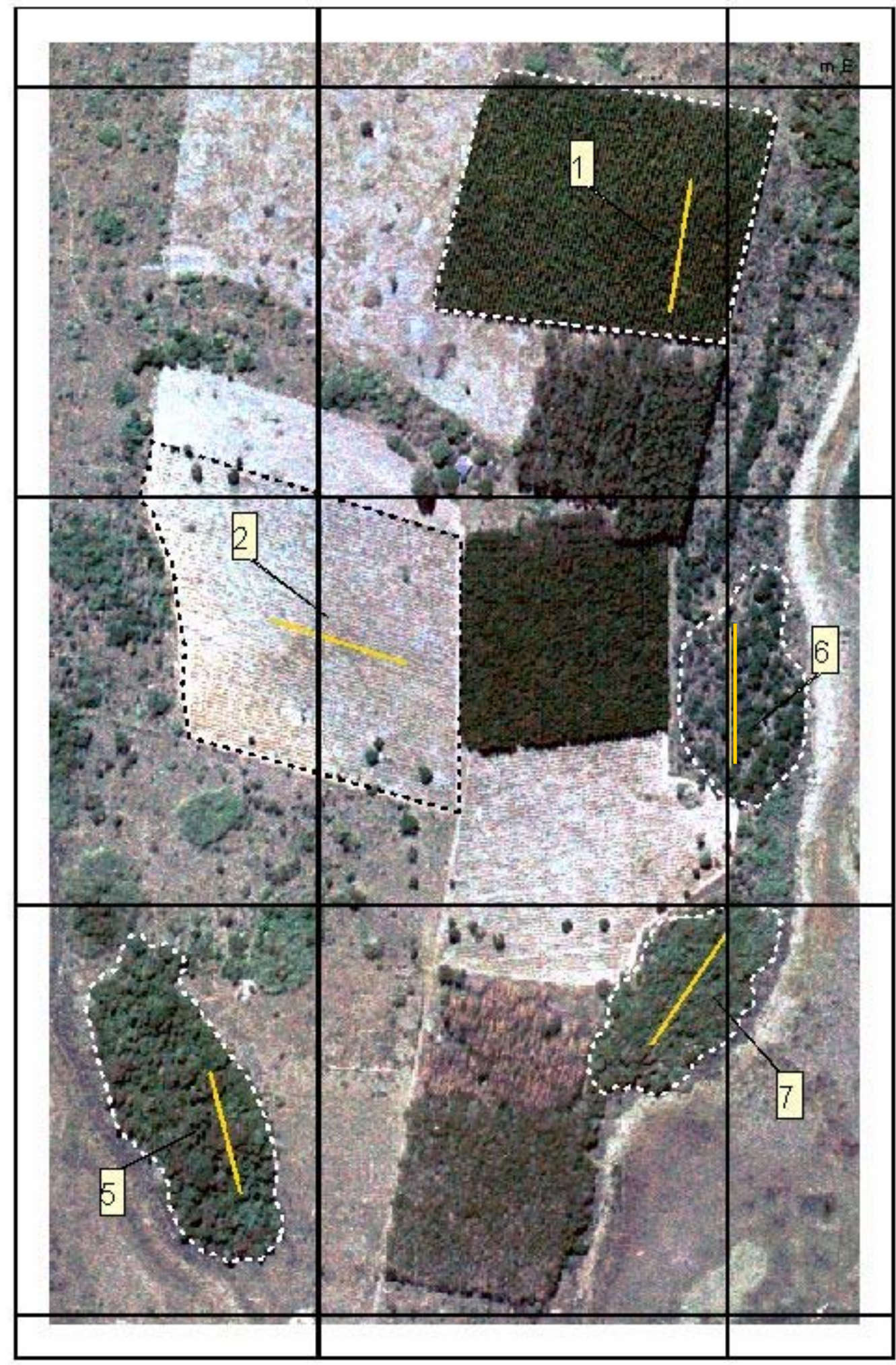

7485000

Escala 1: 5.000

Figura 7 - Foto aérea digitalizada evidenciando os ambientes A1, A2, A5, A6 e A7 e respectiva localização dos transectos/ambientes, na Estação Experimental de Ciências Florestais, Anhembi, SP 


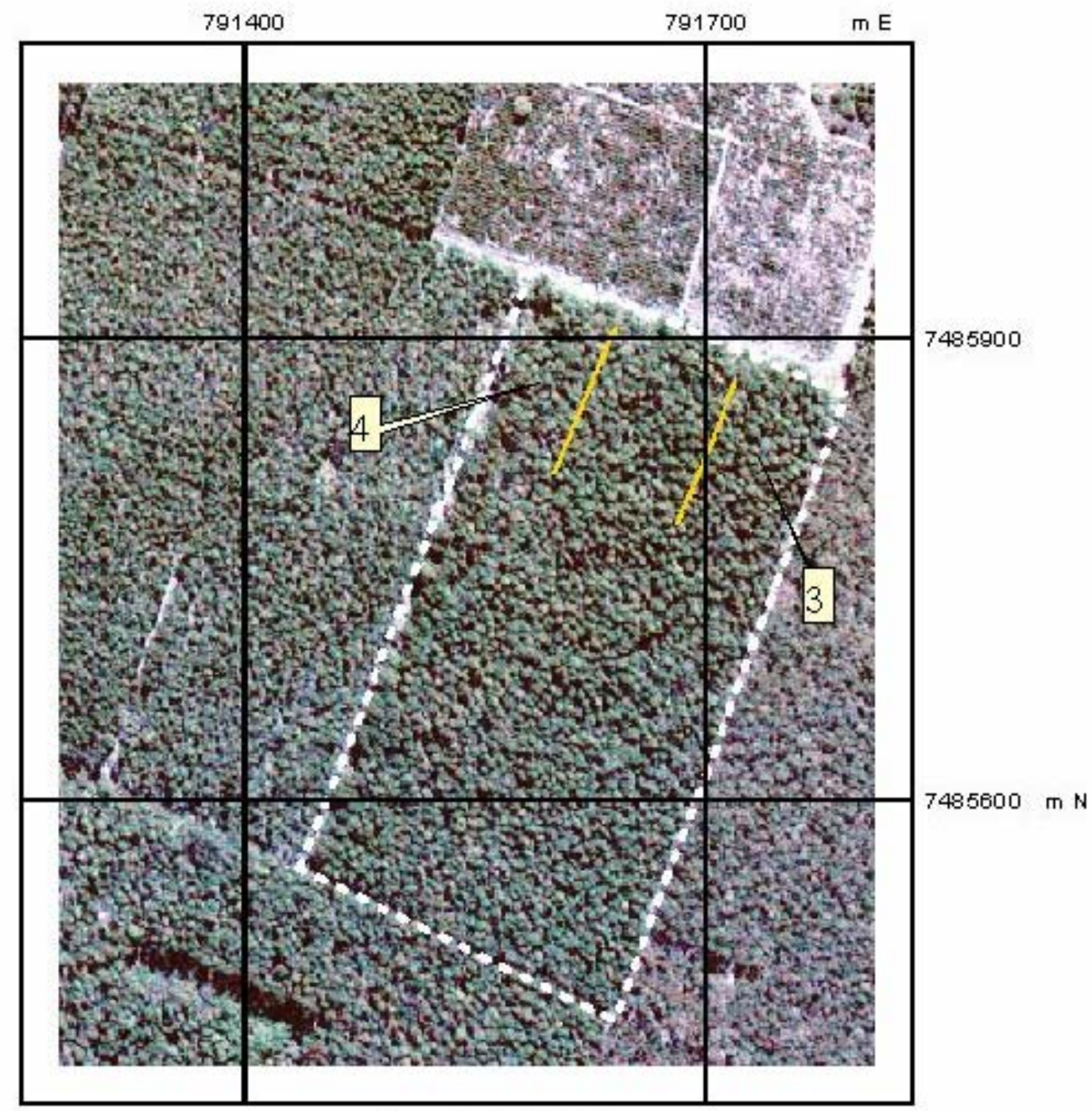

Escala 1: 5.000

Projeçẫo UTM - Fuso 22

Figura 8 - Foto aérea digitalizada evidenciando os ambientes A3 e A4 e respectiva localização dos transectos/ambientes, na Estação Experimental de Ciências Florestais, Anhembi, SP 


\subsection{Identificação dos térmitas}

Os térmitas foram identificados em nível de gênero pelas chaves dicotômicas de Fontes (1983) e Constantino (1999). A identificação das espécies foi feita por comparação com a Coleção de Isoptera do Laboratório de Entomologia Florestal da Escola Superior de Agricultura "Luiz de Queiroz", Universidade de São Paulo (ESALQ/USP), onde o entomológico desta pesquisa está depositado. Após a identificação, as amostras foram encaminhadas à especialista na ordem, visando sua confirmação.

\subsection{Análise dos dados}

\subsubsection{Análise estatística}

Durante 16 meses todos os ambientes foram amostrados quatro vezes e, para evitar a influência de variações sazonais, cada período de quatro meses correspondeu a um bloco. Paralelamente, a amostragem dos sete ambientes em períodos de quatro meses também objetivou viabilizar as coletas devido ao tempo necessário para as atividades em campo e, também, ao grande volume de material para triagem, acondicionamento e armazenagem em laboratório.

Para identificar diferenças quanto a presença e abundância das espécies entre os sete ambientes amostrados, o delineamento experimental foi em blocos ao acaso ao longo do tempo (os quatro períodos de amostragem) com os tratamentos distribuídos em fatorial. Os fatores foram dois: ambientes com sete níveis e espécies com 17 níveis, com quatro repetições. Os dados foram submetidos a análise de variância (ANOVA) e as médias comparadas pelo teste de Tukey a $5 \%$ de probabilidade de erro. Devido a grande quantidade de valores zero, os dados foram transformados por $\sqrt{x+0,5}$. 


\subsubsection{Análise faunística}

A amostragem de térmitas utilizando um transecto por ambiente, forneceu duas medidas. A primeira, riqueza de espécies ( $r$ ), foi calculada pelo somatório do número de espécies coletadas pelos três métodos em cada ambiente. A segunda, abundância relativa, foi calculada a partir do número de encontros de cada espécie nos diversos setores do transecto e não no número de indivíduos (Jones, 2000).

De acordo com Jones et al. (2003), um encontro pode ser definido como o registro de uma espécie em um setor. Assim, o número de encontros por transecto pode ser utilizado para comparar a abundância relativa de térmitas entre ambientes, porém não fornece a abundância absoluta de térmitas por unidade de área.

Neste trabalho foi acrescentada a amostragem através de iscas (Junqueira, 1999), ressaltando que para a(s) espécie(s) que ocorreu(ram) mais de uma vez no mesmo setor, independente do tipo de amostragem, considerouse somente um encontro, evitando assim que indivíduos da mesma colônia fossem considerados mais de uma vez.

\section{a) Caracterização das comunidades}

Para a análise da diversidade da comunidade de térmitas foram calculados:

- o índice de Diversidade de Shannon-Wiaver $\left(\mathrm{H}^{\prime}\right)$ que reflete dois atributos básicos da comunidade: o número de espécies e a equitatividade; 
- o índice de abundância que identifica as espécies predominantes em cada ambiente e que pode ser definido como o número de encontros com a espécie por unidade de superfície (no caso, o transecto) ou volume (Silveira Neto et al., 1995).

- e o Índice de Eqüitabilidade (E) que estima a distribuição das espécies na amostra verificando a homogeneidade da ocorrência numérica das espécies.

Todos os índices foram calculados utilizando o programa ANAFAU (Moraes et al., 2003) que foi desenvolvido pelo setor de Entomologia da ESALQ/USP.

\section{b) Comparação das comunidades}

A análise de Cluster, através do agrupamento das semelhanças entre os sete ambientes avaliados quanto a composição e abundância de espécies, foi utilizada para indicar similaridade entre as comunidades. Esta análise também foi escolhida devido ao grande número de locais de investigação. Os resultados foram expressos na forma de dendograma. 


\section{RESULTADOS E DISCUSSÃO}

Os resultados obtidos nos quatro períodos de amostragem, quando comparados pela análise de variância (ANOVA), mostraram que o efeito de bloco não foi significativo indicando, portanto, que a termitofauna não sofreu variações de um período para outro $(F=0,583 ; g l=3,354 ; P=0,630)$.

Quanto à riqueza e abundância relativa das espécies de térmitas nos sete ambientes amostrados, foram encontradas diferenças significativas $(F=4,515 ; \quad g l=96,354 ; \quad P<0,001)$ entre os ambientes (Tabela 1). Quando comparada a abundância relativa de cada espécie por ambiente, foi possível, pelo programa ANAFAU (Moraes et al., 2003), separar as espécies em cinco categorias: muito abundante, abundante, comum, pouco comum e rara (Tabela 3).

\subsection{Riqueza total de espécies}

Considerando os dados das quatro repetições nos sete ambientes, foram obtidas 1.196 amostras de térmitas, distribuídas em três famílias, sendo a riqueza total de 17 espécies. Por ambiente, a riqueza variou de oito a 13 espécies. A maior riqueza foi encontrada em A7 ( $r=13)$. Nos ambientes A2 e A3, foram encontradas oito e nove espécies respectivamente. Em cada um dos demais ambientes foram coletadas dez espécies (Tabela 1; Figura 9).

De acordo com Lavelle et al. (1997), as comunidades dos chamados engenheiros de ecossistemas - que incluem os térmitas e as minhocas geralmente apresentam uma baixa riqueza de espécies, sendo que as 
comunidades de térmitas com maior diversidade possuem de 20 a 60 espécies, ocasionalmente uma quantidade maior. Jones (2000) referiu que os térmitas têm uma distribuição predominantemente tropical, com a maior riqueza nas florestas tropicais, declinando com o aumento da latitude. A sobrevivência destes insetos é limitada pela temperatura e pela umidade, sendo que poucas espécies ocorrem além de $45^{\circ}$ de latitude.

Na Amazônia brasileira, Bandeira (1979) registrou 21 gêneros de térmitas. Mais recentemente, Constantino (1992) encontrou 64 e 27 espécies em duas localidades no Pará, enquanto Oliveira \& Acioli (2002) registraram 56 espécies no mesmo estado. Riqueza bastante inferior ( $r=18$ espécies) foi relatada por Thomazini \& Thomazini (2002) em diversas áreas no Acre.

$\mathrm{Na}$ região nordeste, Bandeira \& Vasconcellos (2002) relataram para Pernambuco 21 espécies, enquanto Reis \& Cancello (2002) encontraram na Bahia um total de 36 espécies. No centro-oeste, em Mato Grosso, Constantino \& Schlemmermeyer (2000) registraram 76 espécies.

Os dados obtidos em Anhembi mostram uma riqueza intermediária de térmitas quando comparados aos das outras regiões do Brasil. Cancello (2002) encontrou nas localidades do norte da floresta Atlântica cerca de 30 morfoespécies, enquanto que nas do sul (Santa Catarina) registrou uma baixa riqueza, variando de duas a oito morfo-espécies. Riquezas similares às referidas pela autora no sul da floresta Atlântica foram relatadas no Rio Grande do Sul, região subtropical, por Castro \& Diehl (2003) e Diehl et al. (no prelo). 
Tabela 1. Riqueza e abundância relativa média de térmitas (média do número de encontros nas quatro repetições) em sete ambientes florestais em Anhembi, SP

\begin{tabular}{|c|c|c|c|c|c|c|c|}
\hline \multirow{2}{*}{ Espécies } & \multicolumn{7}{|c|}{ Ambientes } \\
\hline & A1 & A2 & A3 & A4 & A5 & A6 & A7 \\
\hline \multicolumn{8}{|l|}{ Kalotermitidae } \\
\hline Glyptotermes sp. & - & - & - & - & 0,25 & - & - \\
\hline Neotermes sp. & - & - & - & - & - & - & 0,25 \\
\hline Rugitermes sp. & - & - & - & - & - & - & 0,50 \\
\hline \multicolumn{8}{|l|}{ Rhinotermitidae } \\
\hline Heterotermes tenuis * & 1,75 & 1,25 & 6,00 & 5,25 & 2,25 & 0,25 & 0,25 \\
\hline \multicolumn{8}{|l|}{ Termitidae } \\
\hline \multicolumn{8}{|l|}{ Apicotermitinae } \\
\hline Apicotermitinae sp.1 * & 7,25 & 9,00 & 2,00 & 5,50 & 3,75 & 5,25 & 5,25 \\
\hline Apicotermitinae sp. 2 * & 6,50 & 3,00 & 3,25 & 3,25 & 1,00 & 6,00 & 3,25 \\
\hline Apicotermitinae sp.3 & 2,00 & 1,75 & - & - & 1,25 & 0,75 & 1,25 \\
\hline Apicotermitinae sp. 4 * & 3,25 & 4,25 & 0,75 & 1,00 & 0,75 & 3,75 & 2,75 \\
\hline Apicotermitinae sp.5 & 0,50 & - & - & - & 0,50 & - & 0,25 \\
\hline Tetimatermes sp. & 0,50 & - & - & 0,50 & 0,25 & 0,25 & 0,50 \\
\hline \multicolumn{8}{|l|}{ Nasutitermitinae } \\
\hline Cornitermes sp. * & 4,25 & 1,25 & 1,75 & 1,75 & - & 1,00 & 0,25 \\
\hline Diversitermes diversimiles * & 0,25 & - & 5,50 & 7,50 & 2,00 & - & - \\
\hline Embiratermes sp. * & 0,25 & 0,75 & 1,50 & 0,25 & 2,25 & 0,50 & 1,50 \\
\hline Nasutitermes aquilinus & - & - & - & - & - & - & 0,25 \\
\hline Rhynchotermes sp. & - & - & 0,25 & 0,25 & - & 0,50 & - \\
\hline \multicolumn{8}{|l|}{ Termitinae } \\
\hline Dihoplotermes sp. & - & 0,25 & - & - & - & 1,00 & 0,25 \\
\hline Neocapritermes sp. & - & - & 0,25 & 0,25 & - & - & - \\
\hline
\end{tabular}

* Médias diferiram significativamente pelo teste de Tukey a 5\% quando comparada a abundância relativa da espécie nos sete ambientes ( $F=4,515$; $g l=96,354$; $\mathrm{P}<0,001)$. 


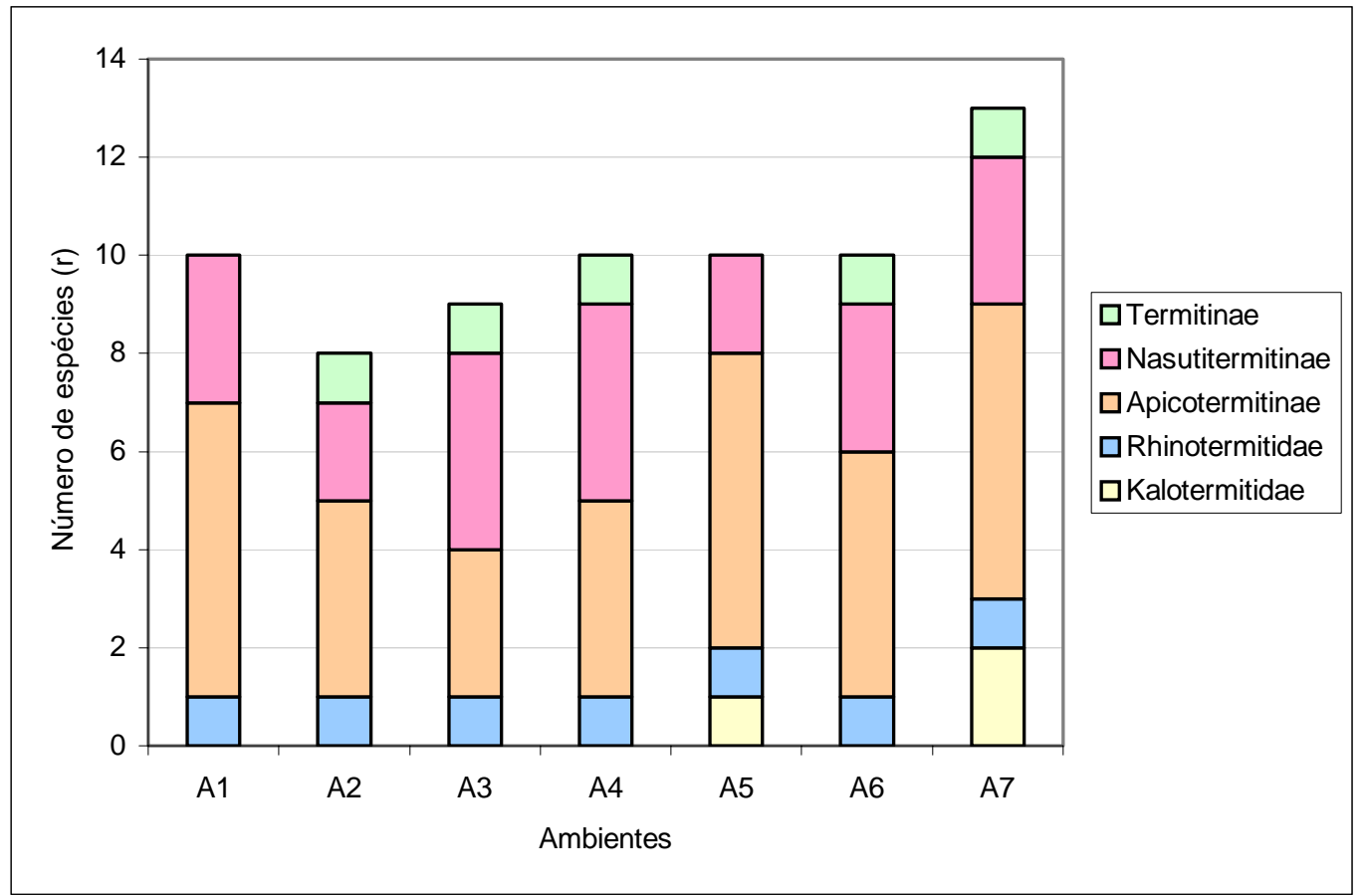

Figura 9 - Distribuição do número de espécies de térmitas nos sete ambientes florestais amostrados em Anhembi, SP

\subsection{Abundância relativa}

A abundância relativa (calculada a partir do número de encontros de cada espécie nos dez setores do transecto) variou nos ambientes amostrados, sendo que para algumas espécies foram encontradas diferenças significativas entre ambientes $(F=4,515 ; g l=96,354 ; P<0,001)$ (Tabela 1, Figura 10). Deve ser lembrado que, como cada transecto continha dez setores, a abundância relativa média (média das quatro repetições) por ambiente pode atingir no máximo o valor dez. A seguir os resultados são apresentados e discutidos por grupo taxonômico. 

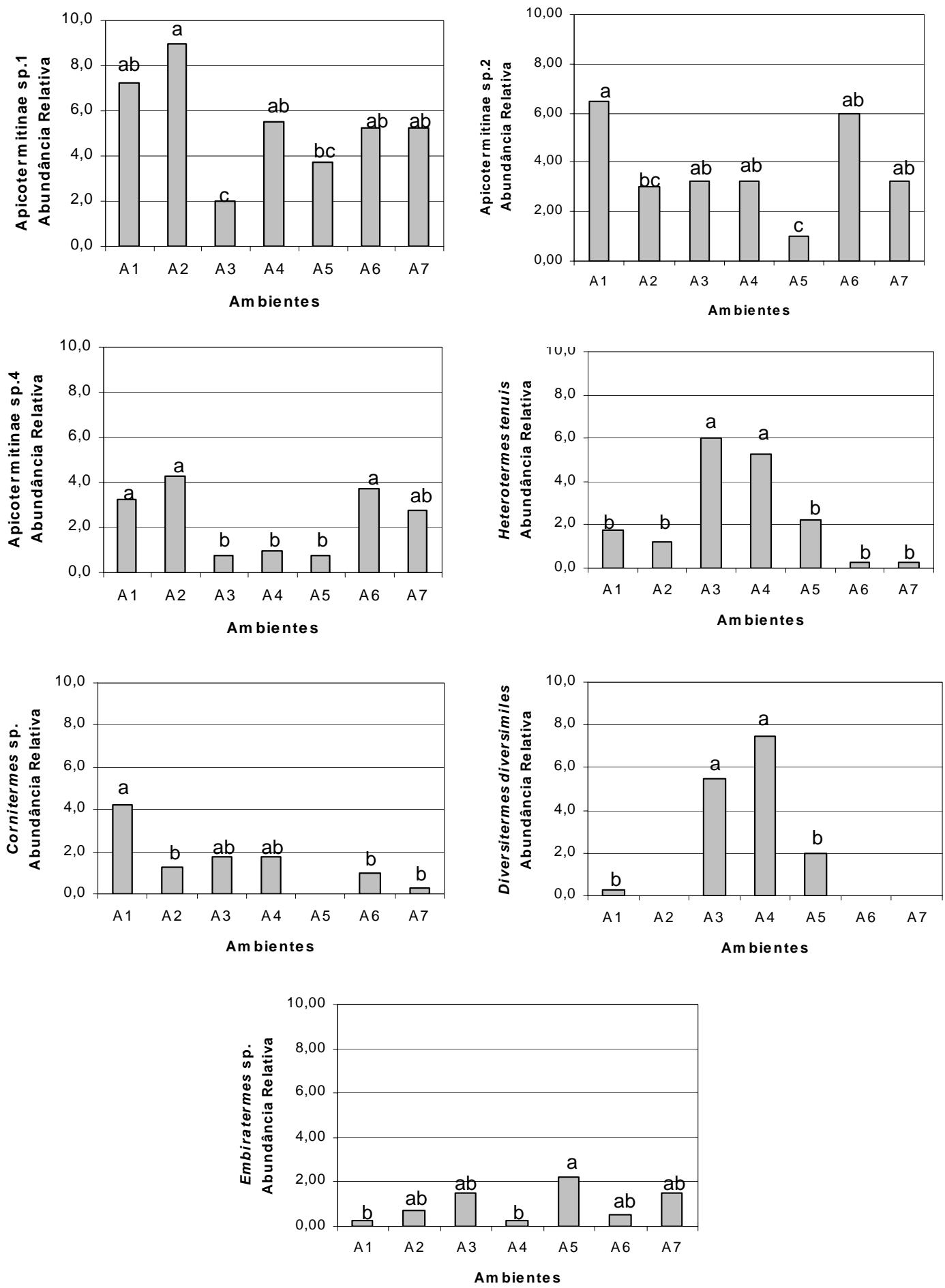

Figura 10 - Abundância das espécies de térmitas nos sete ambientes amostrados. Médias comparadas pelo teste de Tukey a 5\% de probabilidade de erro 


\subsubsection{Família Kalotermitidae}

Esta família foi coletada nos ambientes A5 e A7, não ocorrendo nos outros. No ambiente A5 foi coletada a espécie Glyptotermes sp. com uma abundância relativa de 0,25 encontros médios. Em A7, foram registradas Neotermes sp. e Rugitermes sp. com 0,25 e 0,50 encontros médios, respectivamente (Tabela 1 ). Apesar de não terem sido verificadas diferenças significativas na abundância das espécies de Kalotermitidae entre estes ambientes, é importante ressaltar que A5 e A7 são fragmentos florestais. O primeiro, sofreu exploração seletiva de madeira até 1976, quando passou a ser preservado. O ambiente A7, sobra de um desbaste seletivo realizado em 1986 para instalação de um plantio está, desde então, em processo natural de regeneração.

A ocorrência de calotermitídeos somente nestes ambientes era esperada pela presença de madeira, já que tanto as florestas de eucalipto (A1, A2, A3 e A4) quanto o ambiente A6, que se encontra em estágio de sucessão recente, caracterizam-se pela quantidade reduzida de madeira no solo, alterando, portanto, um dos componentes do nicho de Kalotermitidae. Segundo Constantino (1999) e Constantino \& Schlemmermeyer (2000), nesta família estão os térmitas xilófagos, que vivem em madeira seca, sem contato com o solo. O habitat natural da maior parte das espécies é florestal, mas muitas podem ser encontradas em vegetação aberta, como o cerrado, geralmente condicionada à presença de árvores e madeira. Segundo Mathews (1977) muitas espécies do gênero Neotermes podem forragear no tronco das árvores.

Bandeira et al. (2003) verificaram que todas as espécies de Kalotermitidae encontradas em floresta úmida nos limites da caatinga, em Pernambuco, estavam exclusivamente em madeira. Algumas espécies eram mais abundantes nos locais com distúrbios, sugerindo que florestas com dossel mais aberto, com pouca umidade e maior abundância de madeira seca 
favorecem estas espécies. Como vivem exclusivamente no interior da madeira, podem não sobreviver em locais que não disponham deste recurso.

Segundo Constantino (1999), da família Kalotermitidae, o gênero Glyptotermes tem distribuição pantropical, com quatro espécies registradas para o Brasil, das quais duas na Amazônia (G. perparvus e G. pellucidus), uma no Rio de Janeiro (G. sicki) e outra em São Paulo e Santa Catarina (G. canellae). Neotermes, também com distribuição pantropical, possui nove espécies, ocorrendo em todas as regiões do Brasil, enquanto Rugitermes, com distribuição neotropical (exceto por uma espécie da Polinésia), apresenta quatro espécies que ocorrem nas regiões sul e sudeste do Brasil.

\subsubsection{Família Rhinotermitidae}

Da família Rhinotermitidae foram amostrados, em todos os ambientes, somente indivíduos de Heterotermes tenuis, com abundâncias relativas variando de 0,25 a 6,0 encontros médios (Tabela 1). Nos ambientes A3 e A4, $H$. tenuis apresentou a maior abundância, diferindo significativamente dos demais pelo Teste de Tukey a 5\% (Figura 10). Como nestes ambientes o eucalipto foi implantado em 1991, a maior ocorrência de $H$. tenuis pode estar associada à presença de árvores adultas.

No Brasil, o gênero Heterotermes possui quatro espécies descritas e ocorre em todas as regiões, em vários tipos de habitat, em madeira ou em ninhos difusos no solo (Constantino, 1999). Danos causados por $H$. tenuis foram relatados em diversas culturas (Almeida et al., 1984; Pizano \& Fontes, 1986; Domingos et al., 1988; Almeida \& Alves, 1995; Alves e Almeida, 1995; Campos et al., 1998), incluindo áreas de cultivo de eucalipto. Segundo Raetano et al. (1997), H. tenuis provocou uma mortalidade expressiva em E. grandis com dois anos de idade em Uberlândia, MG, pela atividade de forrageamento sob as cascas das árvores o que deixa uma porta de entrada para o cancro do eucalipto, causado pelo fungo Cryphonectria cubensis. De acordo com Wilcken 
\& Raetano (1998) a ocorrência conjunta térmita/fungo foi altamente prejudicial para o povoamento de eucalipto.

A espécie $H$. tenuis pertence ao grupo funcional dos xilófagos, utilizando madeira (De Souza \& Brown, 1994) além de resíduos orgânicos (Mathews, 1977) como recursos alimentares.

\subsubsection{Família Termitidae}

\subsubsection{Subfamília Apicotermitinae}

Desta subfamília foram coletadas seis espécies, das quais uma pertencente ao gênero Tetimatermes. As demais, foram denominadas pela subfamília seguido por sp.1, sp.2, sp.3, sp.4 e sp.5. Optou-se por esta designação pois algumas destas morfo-espécies, possivelmente, pertencem a um ou mais gêneros novos (L.R. Fontes, comun. pess.).

Apicotermitinae sp.1 foi coletada em todos os ambientes avaliados com uma abundância que variou de 2,00 a 9,00 encontros médios (Tabela 1). Embora mostrando uma tendência de maior abundância relativa no ambiente A2 (plantio de eucalipto de 2000), não diferiu significativamente daquelas observadas em A1, A4, A6 e A7. Paralelamente, nos ambientes A3 (plantio de eucalipto de 1991, com sub-bosque) e A5 (fragmento florestal) foram encontradas as menores abundâncias relativas (Figura 10). Os resultados obtidos em Anhembi poderiam sugerir que a maior abundância relativa desta morfo-espécie estaria vinculada à estruturas vegetacionais menos complexas, como por exemplo plantios recentes de eucalipto.

Coletada em todos os ambientes avaliados, Apicotermitinae sp.2 apresentou abundância relativa de 1,00 a 6,50 encontros médios (Tabela 1; Figura 10). O maior número de encontros foi registrado em $A 1$ (plantio de eucalipto de 2001), não diferindo significativamente dos ambientes A3, A4, A6, 
A7. No ambiente A5 (fragmento florestal) apresentou a menor abundância relativa, semelhante a de A2 (plantio de eucalipto de 2000).

A morfo-espécie Apicotermitinae sp.3 não ocorreu em A3 e A4 (plantios de eucalipto de 1991 com e sem sub-bosque, respectivamente), enquanto que nos demais ambientes a abundância relativa foi baixa $(0,75-2,00)$, não diferindo significativamente entre si (Tabela 1).

Apicotermitinae sp.4 foi coletada em todos os ambientes avaliados, com abundâncias relativas variando de 0,75 a 4,25 encontros médios (Tabela 1). Nos ambientes A1, A2, A6 e A7 esta morfo-espécie apresentou as maiores abundâncias relativas, enquanto as menores foram registradas em A3, A4 e A5 (Figura 10).

Encontrada somente em A1, A5 e A7, Apicotermitinae sp.5 apresentou abundâncias relativas de 0,25 a 0,50 encontros médios. Por sua vez, Tetimatermes sp. ocorreu em A1, A4, A5, A6 e A7 com abundâncias relativas variando de 0,25 a 0,50 encontros médios. Tanto Apicotermitinae sp.5 quanto Tetimatermes sp., não apresentaram diferenças significativas entre as abundâncias registradas nos ambientes em que ocorreram (Tabela 1).

Todas as morfo-espécies de Apicotermitinae foram encontradas em A1. Neste ambiente, o eucalipto foi implantado em setembro de 2001, enquanto as coletas foram realizadas de janeiro de 2002 a maio de 2003. Portanto, este ambiente foi amostrado periodicamente dos cinco aos 20 meses, o início das amostragens correspondendo à fase da floresta em que o solo estava bastante exposto devido ao preparo por gradagem e sulcamento e manejo por coroamento com enxada e roçada mecânica. Por sua vez, a morfo-espécie Apicotermitinae sp.1 apresentou a maior abundância relativa desta subfamília no ambiente A2 (plantio de eucalipto de 2000) onde também foram registradas outras três morfo-espécies de Apicotermitinae.

Segundo Bignell \& Eggleton (2002), as espécies de Apicotermitinae são incluídas nos grupos funcionais dos geófagos, dos intermediários entre geofagia e xilofagia e dos forrageadores de serrapilheira. De Souza \& Brown (1994) 
categorizaram os representantes desta subfamília coletados na floresta Amazônica apenas como geófagos. Quanto ao material coletado em Anhembi, por se tratar de representantes de possíveis gêneros e espécies novos e não haver estudos específicos, ainda não se pode categorizá-los em um ou mais grupos funcionais.

É possível que a grande maioria dos representantes de Apicotermitinae que foram coletados pertença à categoria dos geófagos, pois a sua abundância relativa foi alta em A1 e A2. Estes ambientes, por serem plantios recentes, apresentavam baixa disponibilidade de serrapilheria e/ou de madeira em decomposição avançada, alterando o nicho dos térmitas forrageadores em serrapilheira e intermediários entre xilofagia e geofagia e, portanto, dificultando sua ocorrência. Por outro lado, a grande abundância de espécies geófagas nestes ambientes também não seria esperada devido às alterações microclimáticas decorrentes do manejo silvicultural. Tem sido relatada a fragilidade do grupo funcional dos geófagos quanto à fragmentação ou intensificação do uso das áreas estudadas (De Souza \& Brown, 1994; Eggleton et al.,1995; Eggleton et al., 1996; Eggleton et al., 2002; Bandeira et al., 2003; Jones et al., 2003).

Segundo De Souza \& Brown (1994), alterações de habitat afetam de forma diferenciada as espécies nas comunidades. Os térmitas de hábitos alimentares intermediários e os que se alimentam de serrapilheira são normalmente grandes, com corpo esclerotizado, alimentando-se freqüentemente em lugares abertos, enquanto os geófagos são pequenos, de corpo mole e forrageiam na matriz do solo. Desta forma, parece plausível supor que os geófagos seriam mais afetados por perturbações que levassem à maior exposição do solo e suas alterações microclimáticas decorrentes. Eggleton et al. (1995 e 1996), ao avaliarem os grupos funcionais de térmitas em áreas com diferentes níveis de distúrbios florestais, verificaram que os geófagos predominaram nas áreas em processo de regeneração e de floresta primária, tendo sua riqueza reduzida nas áreas com distúrbios severos e, de acordo com 
Eggleton et al. (2002), de forma mais acentuada do que o dos xilófagos. Entretanto, resultados obtidos em Anhembi, sugerem que as modificações na estrutura vegetacional, decorrentes do cultivo de eucalipto não afetaram de forma significativa a riqueza e a abundância dos térmitas geófagos nos plantios de eucalipto de 2000 e 2001.

No Brasil, estão descritas para a subfamília Apicotermitinae, 15 espécies distribuídas em cinco gêneros. Anoplotermes, com oito espécies descritas, possui uma distribuição neotropical, ocorrendo em todas as regiões. É um gênero bastante heterogêneo e pouco conhecido, sendo que poderá ser dividido em vários outros, quando o grupo for melhor estudado. Ocorre em vários tipos de habitats, principalmente em galerias difusas no solo, alimentando-se de matéria orgânica em decomposição. Algumas espécies podem construir ninhos epígeos e arborícolas. O gênero Aparatermes, com apenas uma espécie descrita e registrada para a Argentina, provavelmente ocorre em todo o Brasil e inclui várias espécies ainda não descritas. Por sua vez, Grigiotermes, com duas espécies descritas, ocorre no cerrado e sudeste e alimenta-se de húmus. Apesar de construir ninhos epígeos, pode ser encontrado em ninhos de outras espécies. Paralelamente, com três espécies já descritas, o gênero Ruptitermes tem distribuição neotropical, ocorre em todas as regiões do Brasil, alimentando-se principalmente de folhas da serrapilheira. Podem viver no solo, em ninhos arborícolas cartonados ou em ninhos de outras espécies (Constantino, 1999). Finalmente, o gênero Tetimatermes, relatado em savana na Amazônia, tem apenas uma espécie descrita e registrada no estado de São Paulo. Com hábitos pouco conhecidos, vive no solo ou em ninhos de outros térmitas (Fontes, 1985).

\subsubsection{Subfamlía Nasutitermitinae}


Desta subfamília foram amostradas cinco espécies de térmitas: Cornitermes sp., Diversitermes diversimiles, Embiratermes sp., Nasutitermes aquilinus e Rhynchotermes sp..

A espécie Cornitermes sp. só não foi coletada no ambiente A5 (fragmento florestal), nos demais apresentou abundâncias relativas variando de 0,25 a 4,25 encontros médios (Tabela 1). Apesar de em A1 (plantio de eucalipto) apresentar a maior abundância relativa, as diferenças não foram significativas das encontradas em A3 e A4. A menor abundância foi encontrada em A7 (sucessão avançada), mas que não diferiu significativamente das registradas nos ambientes A2, A3, A4 e A6 (Figura 11). De acordo com Wilcken \& Raetano (1998), o gênero Cornitermes ocorre em plantios de Eucalyptus spp. atacando raízes das plantas adultas e atacando raízes de mudas de $E$. grandis e de E. citriodora. Por sua vez, C. cumulans é referida em Eucalyptus spp. atacando raízes de plantas adultas, enquanto $C$. bequaerti é responsável pelo ataque às raízes e colo de mudas de E. urophylla. De Souza \& Brown (1994) categorizaram as espécies de Cornitermes coletadas na Amazônia em dois grupos funcionais, sendo Cornitermes sp.a e Cornitermes pugnax xilófagas e Cornitermes sp.b forrageadora de serrapilheira. Mathews (1977) observou, nos estudos realizados em Mato Grosso, que Cornitermes snyderi forrageava em serrapilheira e madeira, já Cornitermes bequaerti forrageava em madeira e trocos de árvores. Constantino (1999) relatou para gênero Cornitermes uma distribuição neotropical, ocorrendo em todas as regiões do Brasil, com dez espécies descritas. Este gênero é encontrado em vários tipos de habitats, tais como floresta, cerrado, campos e pastagens. Várias espécies constroem ninhos epígeos, porém algumas são subterrâneas.

D. diversimiles ocorreu em quatro ambientes (Tabela 1). Em A4 (plantio de eucalipto de 1991) apresentou a maior abundância relativa, com 7,50 encontros médios, não diferindo significativamente de A3. Em A1 (plantio de eucalipto de 2001) apresentou a menor abundância relativa com 0,25 encontros médios, não diferindo de A5 (Figura 10). Nos demais ambientes $D$. 
diversitermes não foi coletada. Constantino (1999) relatou que o gênero Diversitermes está distribuído na América Sul, com três espécies registradas para o Brasil, das quais uma em florestas na Amazônia (D. aporeticus), uma no cerrado ( $D$. diversimiles) e outra em campos na região sul ( $D$. castaniceps), encontradas em ninhos de outros térmitas, aparentemente, alimentam-se de matéria orgânica em decomposição. Porém, Mathews (1977) encontrou no Mato Grosso, além de $D$. diversimiles, a espécie $D$. aporeticus, a primeira forrageando em serrapilheira e madeira e a segunda em madeira.

Coletada em todos os ambientes, Embiratermes sp. apresentou abundâncias relativas variando de 0,25 a 2,25 encontros médios (Tabela 1). Em A5 (fragmento florestal) apresentou a maior abundância, com 2,25 encontros médios, não diferindo significativamente das observadas em A2, A3, A6 e A7. As menores abundâncias foram registradas nos ambientes A1 e A4 (plantios de eucalipto de 2001 e 1991, respectivamente), diferindo significativamente da encontrada em A5 (Figura 10). Para o gênero Embiratermes é referida distribuição neotropical, com oito espécies registradas para o Brasil, ocorrendo em quase todas as regiões, exceto no sul. É encontrado em vários tipos de habitats, no solo ou em ninhos de outros térmitas (exceto E. neotenicus que constrói ninhos epígeos na Amazônia) alimentando-se de madeira em decomposição (Constantino, 1999). De Souza e Brown (1994) consideraram duas espécies de Embiratermes coletadas na Amazônia brasileira como pertencentes ao grupo funcional dos geófagos. Porém, Wilcken \& Raetano (1998) referem Embiratermes spp. provocando danos às raízes de mudas de $E$. grandis e de vários híbridos de Eucalyptus.

A espécie $N$. aquilinus com abundância relativa de 0,25 encontros médios (Tabela 1), foi coletada somente no ambiente A7 (sucessão avançada). Constantino (1999) referiu que o gênero Nasutitermes tem distribuição pantropical, ocorrendo em todas as regiões do Brasil onde foram registradas 47 espécies. São encontradas em todos os tipos de habitats alimentando-se, principalmente, de madeira. Os ninhos, em geral, são arborícolas e cartonados, 
embora algumas espécies do cerrado construam ninhos epígeos. De Souza \& Brown (1994) incluíram as espécies deste gênero coletadas na Amazônia nos grupos funcionais dos xilófagos e dos forrageadores em serrapilheira.

Rhynchotermes sp. com abundâncias relativas de 0,25 e 0,50 encontros médios, foi coletada em A3, A4 e A6, não diferindo significativamente (Tabela 1). O gênero apresenta uma distribuição pantropical com todas as cinco espécies descritas ocorrendo no cerrado. Segundo Mathews (1977), suas espécies têm hábitos subterrâneos, forrageando em folhas presentes na serrapilheira. Entretanto, Wilcken \& Raetano (1998) referem Rhynchotermes spp. provocando danos às raízes de mudas de E. grandis.

\subsubsection{Subfamília Termitinae}

Desta subfamília foram coletadas duas espécies. A primeira Dihoplotermes sp. com abundâncias relativas de 0,25 e 1,0 encontros médios foi encontrada em A2, A6 e A7. A segunda, Neocapritermes sp., ocorreu somente em A3 e A4 com abundância relativa de 0,25 encontros médios. Ambas as espécies não apresentaram diferenças significativas entre as abundâncias registradas nos ambientes em que ocorreram (Tabela 1). Segundo Constantino (1999), o gênero Dihoplotermes é endêmico do Brasil e apresenta somente uma espécie descrita ( $D$. inusitatus) que ocorre no Brasil central e sudeste, em ninhos de Cornitermes, em cerrado e em habitats alterados, sendo sua biologia pouco conhecida. Segundo Mathews (1977), D. inusitatus utiliza húmus como ítem alimentar e foi encontrado, no Mato Grosso, em ninhos de $C$. bequaerti já ocupados por outras espécies, incluindo Curvitermes spp. Subulitermes sp. e Heterotermes sp.. O outro gênero, Neocapritermes apresenta distribuição neotropical e, no Brasil, ocorre em todas as regiões, com 15 espécies descritas. Ocupa vários tipos de habitats, incluindo ninhos de outros térmitas, apresentando hábitos subterrâneos e alimentando-se da madeira encontrada no chão. Entretanto, Wilcken \& Raetano (1998) referem N. 
opacus provocando danos em raízes de Eucalyptus spp., corroborando as observações de Mathews (1977), que encontrou N. opacus: forrageando em maderia, árvores e raízes.

\subsection{Caracterização das comunidades}

Os dois componentes da diversidade são a riqueza (r), isto é, o número de espécies e a abundância, que indica como o total de indivíduos encontra-se distribuído entre as espécies observadas, fornecendo um índice de uniformidade ou eqüitabilidade. Em comunidades com altos índices de eqüitabilidade, cada espécie contribui com um número semelhante de indivíduos para o total de indivíduos observados. A eqüitabilidade é considerada baixa quando uma ou algumas espécies concentram a maior representação proporcional da comunidade, sendo estas consideradas espécies dominantes (Odum, 1988).

Os térmitas, como são insetos eussociais, possuem colônias que podem conter de algumas centenas a milhares de indivíduos, dependendo da espécie. Assim, o número de indivíduos não é utilizado como um indicativo de abundância, pois, por exemplo, o fato de terem sido amostrados dez ou mais indivíduos forrageando em uma isca, não fornece um número real da abundância desta espécie, uma vez que todos ou a grande maioria dos indivíduos podem ser da mesma colônia. Para contornar este problema, o número de encontros com a espécie, nos pontos ou setores de um transecto, tem sido usado como indicativo do quanto esta espécie representa, em termos de abundância, para a diversidade local (Jones, 2000).

Em Anhembi, os ambientes que apresentaram a maior riqueza de espécies de térmitas nem sempre obtiveram os maiores índices de diversidade (Tabela 2). Este fato é decorrente da utilização do Índice de Shannon-Wiaver $\left(\mathrm{H}^{\prime}\right)$, o qual, segundo Odum (1988) é um dos melhores índices para 
comparação de comunidades, avaliando tanto o número de espécies amostradas quanto a sua representação proporcional na amostra.

As maiores diversidades ocorreram em A5 (fragmento florestal) e A7 (sucessão avançada), seguindo-se a dos ambientes A1 (plantio de 2001) e A3 (plantio de 1991 com sub-bosque). A diversidade encontrada em A4 (plantio de 1991) não diferiu da registrada em $A 3$. Por fim, os menores índices de diversidade foram para os ambientes A6 (sucessão recente) e A2 (plantio de 2000), neste último tendo sido encontrada a menor diversidade.

Tabela 2. Riqueza de espécies de térmitas ( $r)$, diversidade $\left(H^{\prime}\right)$ e eqüitabilidade (E) nos sete ambientes florestais avaliados em Anhembi, SP

\begin{tabular}{ccccc}
\hline Ambientes & $\begin{array}{c}\text { Riqueza de } \\
\text { espécies }(\mathrm{r})\end{array}$ & $\begin{array}{c}\text { Diversidade } \\
\text { Shannon-Wiaver }\left(\mathrm{H}^{\prime}\right)\end{array}$ & Intervalo & Eqüitabilidade (E) \\
\hline A1 & 10 & $1,86 \mathrm{~b}$ & $1,85-1,88$ & 0,81 \\
A2 & 8 & $1,66 \mathrm{e}$ & $1,64-1,68$ & 0,80 \\
A3 & 9 & $1,83 \mathrm{bc}$ & $1,82-1,85$ & 0,83 \\
A4 & 10 & $1,80 \mathrm{~cd}$ & $1,79-1,82$ & 0,78 \\
A5 & 10 & $2,02 \mathrm{a}$ & $2,00-2,05$ & 0,88 \\
A6 & 10 & $1,77 \mathrm{~d}$ & $1,75-1,80$ & 0,77 \\
A7 & 13 & $1,98 \mathrm{a}$ & $1,96-2,02$ & 0,78 \\
\hline
\end{tabular}

Eggleton et al. (1996) registraram comunidades de térmitas mais heterogêneas nas áreas semelhantes às de florestas primárias quando comparadas às das áreas com distúrbios mais acentuados e que apresentaram comunidades mais homogêneas. Assim, para Anhembi, poder-se-ia sugerir que a maior diversidade observada nos ambientes A5 (fragmento florestal) e A7 (sucessão avançada), também seria decorrente da maior complexidade vegetacional e, portanto, da maior disponibilidade de micro-habitats para os térmitas. O baixo valor do índice de eqüitabilidade em A7, por sua vez, estaria sugerindo uma distribuição desigual da abundância. Segundo Odum (1988), a diversidade de espécies tende a aumentar durante a sucessão ecológica, 
entretanto esta tendência não continua, obrigatoriamente, nos estágios mais velhos ou maduros. Tal fato pode explicar o maior número de espécies $(r=13)$ em A7.

No ambiente A1, esperava-se encontrar a menor diversidade de térmitas, já que no início do período de amostragem, com mudas de cinco meses, o solo estava bastante exposto. Entretanto, partindo-se do pressuposto que antes deste plantio uma outra floresta de eucalipto (madura) ocupava a mesma área, é possível que a diversidade de térmitas ainda não apresente os efeitos da redução da complexidade vegetacional.

Neste dois ambientes - A3 e A4 - os índices de diversidade foram semelhantes. Com o plantio de eucalipto realizado na mesma data, a única diferença foi a regeneração do sub-bosque em A3, que pode ter levado a maior eqüitabilidade neste ambiente, sugerindo uma distribuição mais homogênea da diversidade.

Em A6, o índice de diversidade foi bastante baixo, porém, não diferiu significativamente do registrado em A4. Este resultado era esperado por A6 ser ambiente de sucessão recente, com predomínio de vegetação rasteira e, portanto, com grande incidência de luz solar. No ambiente A6 foi encontrado o menor índice de eqüitabilidade das sete comunidades de térmitas. A distribuição heretogênea da abundância, com algumas espécies concentrando o maior número de encontros, acaba por reduzir o valor da diversidade, uma vez que o índice de diversidade de Shannon-Wiaver considera os dois componentes da diversidade - riqueza e abundância.

Finalmente, no ambiente A2 (plantio de eucalipto em 2000) foram registrados tanto a mais baixa diversidade $(1,66)$, quanto a menor riqueza de espécies ( $r=8)$, entretanto, o índice de eqüitabilidade, apresentou valor médio em relação ao dos demais ambientes. Em A2, as amostragens foram iniciadas quando a floresta estava com cerca de dez meses, estendendo-se pelos 18 meses subseqüentes. Assim, neste ambiente, a redução da diversidade de térmitas seria uma conseqüência da menor complexidade vegetacional. Como 
os ambientes A1 (plantio 2001) e A5 (fragmento florestal) são próximos de A2, e apresentam índices de diversidade superiores, é possível sugerir que durante o segundo ano pós-plantio de eucalipto ocorreriam as maiores perdas na riqueza de térmitas, enquanto que a abundância não seria muito afetada.

De acordo com a abundância relativa de cada espécie por ambiente foi possível separá-las em cinco categorias: muito abundante, abundante, comum, pouco comum e rara (Tabela 3).

Tabela 3. Distribuição das categorias de abundância (teste ANAFAU) de cada espécie por ambiente avaliado ( $m a=$ muito abundante; $a=$ abundante; $\mathrm{c}=$ comum; $\mathrm{p}=$ pouco comum; $r=$ rara)

\begin{tabular}{|c|c|c|c|c|c|c|c|}
\hline \multirow{2}{*}{ Espécies } & \multicolumn{7}{|c|}{ Ambientes } \\
\hline & A1 & A2 & A3 & A4 & A5 & A6 & A7 \\
\hline Glyptotermes sp. & - & - & - & - & r & - & - \\
\hline Neotermes sp. & - & - & - & - & - & - & $\mathrm{p}$ \\
\hline Rugitermes sp. & - & - & - & - & - & - & $c$ \\
\hline Heterotermes tenuis & c & C & $\mathrm{ma}$ & $\mathrm{ma}$ & a & $\mathrm{p}$ & $p$ \\
\hline Apicotermitinae sp.1 & $\mathrm{ma}$ & $\mathrm{ma}$ & C & $\mathrm{ma}$ & $\mathrm{ma}$ & $\mathrm{ma}$ & ma \\
\hline Apicotermitinae sp.2 & $\mathrm{ma}$ & c & c & c & c & $\mathrm{ma}$ & $\mathrm{ma}$ \\
\hline Apicotermitinae sp.3 & c & c & - & - & c & c & c \\
\hline Apicotermitinae sp.4 & c & c & $p$ & c & c & $\mathrm{ma}$ & $\mathrm{ma}$ \\
\hline Apicotermitinae sp.5 & r & - & - & - & c & - & $\mathrm{p}$ \\
\hline Tetimatermes sp. & r & - & - & $\mathrm{p}$ & r & $\mathrm{p}$ & $\mathrm{c}$ \\
\hline Cornitermes sp. & c & c & c & c & - & c & $\mathrm{p}$ \\
\hline Diversitermes diversimiles & $r$ & - & $\mathrm{ma}$ & $\mathrm{ma}$ & c & - & - \\
\hline Embiratermes sp. & r & c & c & r & a & $\mathrm{p}$ & C \\
\hline Nasutitermes aquilinus & - & - & - & - & - & - & $p$ \\
\hline Rhynchotermes sp. & - & - & r & r & - & $\mathrm{p}$ & - \\
\hline Dihoplotermes sp. & - & $\mathrm{p}$ & - & - & - & c & $\mathrm{p}$ \\
\hline Neocapritermes sp. & - & - & r & $r$ & - & - & - \\
\hline Riqueza de espécies (r) & 10 & 8 & 9 & 10 & 10 & 10 & 13 \\
\hline
\end{tabular}


No ambiente A1, Apicotermitinae sp.1 e Apicotermitinae sp.2 foram categorizadas como muito abundantes, enquanto $H$. tenuis, Apicotermitinae sp.3, Apicotermitinae sp.4 e Cornitermes sp. ficaram na categoria de comuns. Como espécies raras foram registradas Apicotermitinae sp.5, Tetimatermes sp., Diversitermes diversimiles e Embiratermes sp., representando o maior número de espécies nesta categoria entre os sete ambientes avaliados (Tabela 3).

Somente Apicotermitinae sp.1 foi categorizada como muito abundante no ambiente A2, que apresentou, por sua vez, o maior número de espécies na categoria de comuns: H. tenuis, Apicotermitinae sp.2, Apicotermitinae sp.3, Apicotermitinae sp.4, Cornitermes sp. e Embiratermes sp.. Em pouco comum foi categorizada somente Dihoplotermes sp. (Tabela 3).

Para o ambiente A3 pertenceram a categoria de muito abundantes as espécies $H$. tenuis e $D$. diversimiles. Como comuns foram categorizadas Apicotermitinae sp.1, Apicotermitinae sp.2, Cornitermes sp. e Embiratermes sp. Como pouco comum foi registrada somente Apicotermitinae sp.4 e, como raras, Rhynchotermes sp. e Neocapritermes sp. (Tabela 3).

Em A4, H. tenuis, Apicotermitinae sp.1 e $D$. diversimiles foram registradas como muito abundantes; Apicotermitinae sp.2, Apicotermitinae sp.4 e Cornitermes sp. como comuns; Tetimatermes sp. como pouco comum e, finalmente, Embiratermes sp., Rhynchotermes sp. e Neocapritermes sp. foram categorizadas como raras (Tabela 3).

O ambiente A5 apresentou somente uma espécie, Apicotermitinae sp.1 na categoria de muito abundante e, paralelamente, foi o único ambiente a apresentar espécies na categoria de abundante: $H$. tenuis e Embiratermes sp. $\mathrm{Na}$ categoria de comuns foram encontradas Apicotermitinae sp.2, Apicotermitinae sp.3, Apicotermitinae sp.4, Apicotermitinae sp.5 e $D$. diversimiles. Como espécie rara foi registrada apenas Tetimatermes sp. (Tabela 3).

No ambiente A6, Apicotermitinae sp.1, Apicotermitinae sp.2 e Apicotermitinae sp.4 foram categorizadas como muito abundantes. Como 
comuns foram registradas as espécies Apicotermitinae sp.3, Cornitermes sp. e Dihoplotermes sp.. Na categoria de pouco comuns foram encontradas $H$. tenuis, Tetimatermes sp., Embiratermes sp. e Rhynchotermes sp. (Tabela 3).

Finalmente, para o ambiente A7, Apicotermitinae sp.1, Apicotermitinae sp.2 e Apicotermitinae sp.4 foram categorizadas como muito abundantes; Rugitermes sp., Apicotermitinae sp.3, Tetimatermes sp. e Embiratermes sp. como comuns e, finalmente, Neotermes sp., H. tenuis, Apicotermitinae sp.5, Cornitermes sp., $N$. aquilinus e Dihoplotermes sp. como pouco comuns (Tabela 3).

De acordo com Santos \& Marques (1996), as comunidades com os maiores índices de diversidade tendem a ser mais estáveis, garantindo a sobrevivência de espécies raras e, aparentemente, sem importância e que, no entanto, podem ser fundamentais na manutenção da biodiversidade e do equilíbrio no momento em que fatores ecológicos limitantes são alterados.

Para De Souza \& Brown (1994), a alta proporção de espécies raras e a baixa riqueza de espécies em fragmentos florestais isolados na Amazônia, poderia ser decorrente de dois processos. No primeiro caso, as espécies teriam sido excluídas ao acaso, isto é, o fragmento foi originado de uma parte da floresta que continha, naturalmente menor número de espécies do que as áreas próximas. Outra possibilidade seria considerar o aumento da sobreposição de nichos, onde as populações otimizam a utilização do recurso em resposta à redução da sua disponibilidade. Em comunidades muito competitivas, a sobreposição de nichos não é tolerada o que, portanto, reduz sua amplitude. Quanto mais extremos os limites, mais suscetível a comunidade será às flutuações ambientais. Conseqüentemente, a população se tornará cada vez menor, à ponto de ser impossível restabelecer uma população viável, mesmo após uma pequena flutuação ambiental. Portanto, a fragmentação promoveria o desaparecimento de espécies tanto pela exclusão de populações da área, quanto pela mudança de espécies do status de abundante para rara e de rara para extinta. 
Verifica-se (Figura 11) que no ambiente A1, 40,0\% das espécies são raras, em A2 esta categoria não é registrada, em A3, 22,2\% das espécies são raras, em A4 e A5 este freqüência eleva-se para 30,0\% e em A6 e A7 novamente não são registradas espécies raras. As implicações decorrentes da presença de maior ou menor proporção de espécies raras, ainda não estão claras, o que leva a indicar um acompanhamento de cada ambiente ao longo do tempo com o objetivo de avaliar se, realmente, as espécies raras estariam mudando para o status de extintas, sendo substituídas ou não por outras espécies. Jones et al. (2003) sugeriram que a intensificação do uso do solo aumenta a perda das espécies de térmitas dependentes da floresta, as quais não são substituídas por espécies não associadas à floresta.

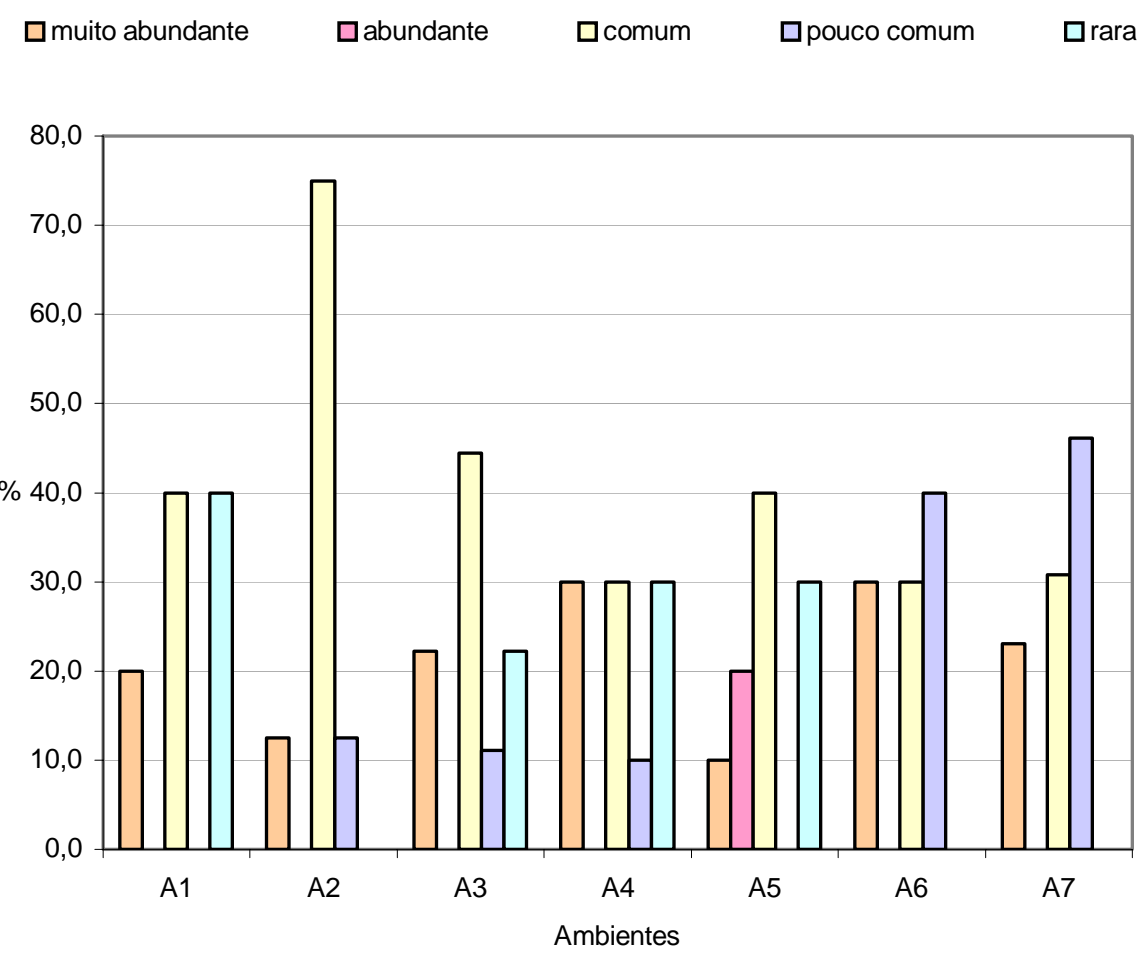

Figura 11 - Distribuição das freqüências de espécies muito abundantes, abundantes, comuns, pouco comuns e raras, entre os sete ambientes amostrados em Anhembi, SP 


\subsection{Comparação das comunidades}

A composição das espécies de térmitas nos sete ambientes florestais em Anhembi foi comparada através da análise de Cluster e os resultados expressos na forma de dendograma (Figura 12). Este último, tem sido utilizado para avaliar a similaridade quanto a composição de espécies de térmitas entre ambientes, sendo obtido, tanto pelo cálculo do índice de similaridade de Sörensen (Mill, 1982; De Souza \& Brown, 1994; Bandeira et al., 2003), quanto pela análise de Cluster (Jones, 2000).

Em Anhembi, foi possível identificar três grupos de acordo com a riqueza e abundância de espécies. Os ambientes mais semelhantes foram A3 e A4 que, junto com o ambiente A5, formaram o primeiro grupo. Neste caso, seria esperada uma grande semelhança entre A3 e A4 justamente por ambos serem formados por um plantio de E. urophylla realizado em agosto de 1991, e cuja única diferença está no sombreamento devido a regeneração do sub-bosque apenas em A3. Além disso, A3 e A4 não apresentaram diferenças significativas nos valores dos índices de diversidade de Shannon-Wiever, apesar do primeiro apresentar maior eqüitabilidade (Tabela 2). Por sua vez, o fragmento florestal A5, incluído neste grupo, apresentou os maiores valores de diversidade e eqüitabilidade.

O segundo grande grupo está formado pelos ambientes $A 1$ (plantio de eucalipto de 2001), A2 (plantio de eucalipto de 2000) e A6 (sucessão recente) que apresentaram a maior similaridade, ressaltando que para o ambiente A2 foram registrados os valores mais baixos de riqueza e diversidade (Tabela 2).

Por fim, encontra-se isolado o ambiente A7 (sucessão avançada), bastante diferente dos outros dois grupos. Este ambiente foi o único que apresentou valores extremos quando comparados os índices de diversidade e eqüitabilidade. Para a diversidade foi registrado o segundo maior índice (não 
diferindo significativamente de A5), porém apresentou uma eqüitabilidade muito baixa (Tabela 2).

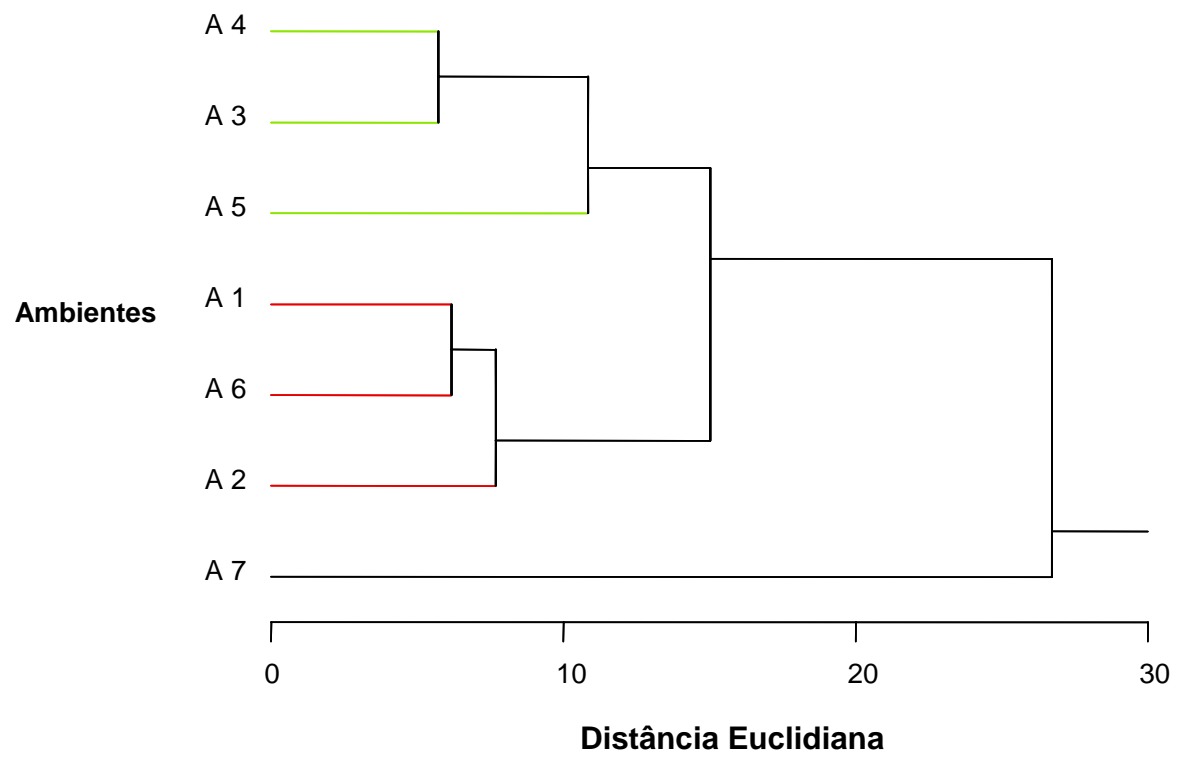

Figura 12 - Análise de Cluster indicando a similaridade entre as comunidades de térmitas (quanto a composição e a abundância) dos sete ambientes florestais amostrados em Anhembi, SP

\subsection{Considerações finais}

Nos ecossistemas terrestres os térmitas são os maiores responsáveis pela decomposição da matéria orgânica, mineralização e ciclagem de nutrientes, influenciando as propriedades e a estrutura do solo (Collins, 1981; Berti Filho, 1995; Lavelle et al., 1997; Bignell \& Eggleton, 2002), portanto, alterações nas comunidades destes insetos, poderiam comprometer de forma significativa o ecossistema. Os resultados obtidos para Anhembi indicam que mudanças na estrutura vegetacional - decorrentes tanto das atividades 
silviculturais, quanto do estágio sucessional dos fragmentos - afetaram os dois componentes (riqueza e abundância) da diversidade dos térmitas. O fato das abundâncias relativas de algumas espécies de térmitas modificarem-se entre os ambientes avaliados, pode ser um indicativo de que espécies com potencial de para se tornarem pragas poderiam aumentar sua abundância à medida que aumentam os distúrbios, porém não de forma tão pronunciada (Figura 13), corroborando o referido por Jones et al. (2003) de que algumas populações de térmitas aumentam significativamente com a intensificação da agricultura, o que é menos evidente em áreas de floresta tropical. O aumento de uma dada espécie pode ser decorrente da sua presença no conjunto original de espécies locais ou de sua introdução através das atividades humanas. Porém, a maior dificuldade reside em encontrar diferenças significativas quando um pequeno gradiente é amostrado.

Apesar dos sete ambientes serem relativamente próximos, portanto, sem grandes variações no que se refere as características do solo, sugere-se que novos estudos sejam realizados avaliando possíveis correlações entre a composição do solo e a diversidade térmitas.

Paralelamente, a ocorrência de algumas espécies de térmitas estaria vinculada à presença de restos de madeira no solo. Estas espécies não teriam potencial de causar danos em mudas e/ou árvores já que nidificam e alimentam-se nesta madeira, sugerindo que a não retirada de resto de madeira acarretaria em aumento da diversidade da comunidade local.

O trabalho de Jones et al. (2003) é o único que propõe ações que visam a recuperação das comunidades de térmitas. $O$ autores sugeriram que ao deixar madeira morta no solo da floresta após o distúrbio, o processo de recuperação das comunidades de térmitas é acelerado devido ao aumento da abundância e da riqueza dos térmitas xilófagos e geófagos. Além disso, a utilização de práticas diferentes daquelas atualmente empregadas para a retirada de madeira, poderia preservar tanto a fauna de térmitas quanto a de formigas. O aumento do tamanho dos fragmentos, reduzindo e efeito de bordas, 
teria um efeito positivo na sobrevivência das espécies que dependem da floresta e, finalmente, a adoção de corredores conectando os fragmentos, poderia auxiliar a recolonização por térmitas, aumentando o seu potencial de dispersão.

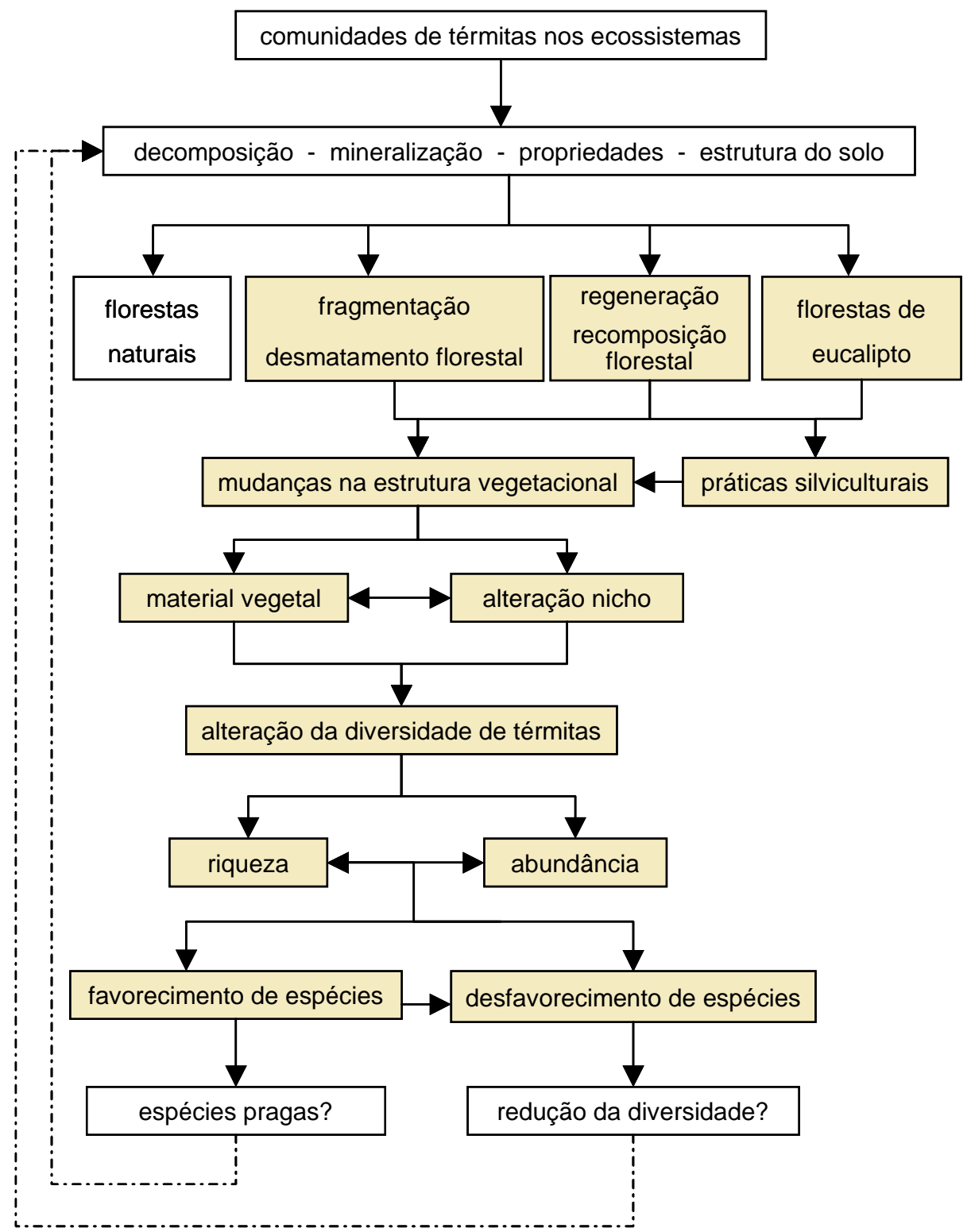

Figura 13 - Esquema evidenciando a problemática dos térmitas em florestas de eucalipto 


\section{CONCLUSÕES}

- Apesar da diversidade de térmitas variar entre os ambientes amostrados, a riqueza apresentou valores intermediários quando comparados aos já registrados para as regiões subtropical e tropical do Brasil.

- A distribuição das espécies de Apicotermitinae indica que este grupo não tem sua riqueza e abundância reduzidas devido às mudanças na estrutura vegetacional, decorrentes da implantação do eucalipto.

- O aumento da abundância de Heterotermes tenuis está vinculado à presença de árvores adultas na área.

- A ocorrência de representantes da família Kalotermitidae está condicionada à presença de madeira sobre o solo. Alterações neste componente do nicho dificultam ou mesmo impedem a ocorrência de calotermitídeos em plantios de eucalipto e nos fragmentos florestais em estágio de sucessão recente.

- O período mais crítico à redução da diversidade de térmitas seria o segundo ano da implantação da floresta de eucalipto, pois parte das espécies ficou um tempo bastante longo em ambiente sem vegetação, com grande incidência de luz solar, condições estas não adequadas para muitos térmitas. Por outro lado, o solo da floresta de eucalipto 
em implantação, pela ausência do dossel, ainda encontra-se exposto e, assim, sem condições adequadas para abrigar novas comunidades de térmitas.

- Após a floresta de eucalipto atingir a maturidade, a presença ou não de sub-bosque parece não influenciar significativamente a riqueza de espécies de térmitas, porém pode contribuir para uma distribuição mais homogênea da diversidade decorrente da maior disponibilidade de micro-habitats proporcionada por uma estrutura vegetacional mais complexa.

- Sugerem-se mais estudos taxonômicos sobre térmitas associados a cultivos de eucalipto e fragmentos florestais para o estado de São Paulo, principalmente porque, neste trabalho foram registrados, pela primeira vez para este estado, indivíduos de Diversitermes diversimiles e Rhynchotermes sp.. Esta sugestão é reforçada pelo fato de terem sido coletados representantes, possivelmente, de dois gêneros de Apicotermitinae ainda não descritos. 


\section{REFERÊNCIAS BIBLIOGRÁFICAS}

ALMEIDA, J.E.M.; ALVES, S.B. Seleção de armadilhas para captura de Heterotermes tenuis (HAGEN). Anais da Sociedade Entomológica do Brasil, v.24, n.3, p.619-624, 1995.

ALMEIDA, M.M.B. de; CALIL, A.C.P.; RODRIGUES, M.G. Constatação da ocorrência de cupins dos gêneros Heterotermes, Coptotermes, Cornitermes em tocos de seringueira (Hevea spp.) no Estado do Pará. In: SIMPÓSIO DO TRÓPICO ÚMIDO, 1., Belém, 1984. Anais. Belém: Embrapa, 1984. p.131141.

ALVES, A.N.; WILCKEN, C.F.; RAETANO, C.G. Controle de cupins subterrâneos (Isoptera) em plantios de eucalipto com imidacloprida e dissulfoton mais triadimenol. In: CONGRESSO BRASILEIRO DE ENTOMOLOGIA, 16., Salvador, 1997. Resumos. Salvador: Sociedade Entomológica do Brasil, 1997. p.253.

ALVES, S.B.; ALMEIDA, J.E.M. de. Novas alternativas para o controle microbiológico de cupins. In: BERTI FILHO, E.; FONTES, L.R. (Ed.). Alguns aspectos atuais da biologia e controle de cupins. Piracicaba: FEALQ, 1995. p.95-102.

ARAÚJO, R.L. Catálogo dos Isoptera do Novo Mundo. Rio de Janeiro: Academia Brasileira de Ciências, 1977. 92p. 
AGOSTI, D.; ALONSO, L.E. The all protocol: a standart protocol for the collection of ground-dwelling ants. In: AGOSTI, D.; MAJER, J.D.; ALONSO, L.E.; SCHULTZ, T.R. (Ed.). Ants: standard methods for measuring and monitoring biodiversity. London: Smithsonian Institution Press, 2000. p. 204206.

BANDEIRA, A.G. Ecologia de cupins (Insecta: Isoptera) da Amazônia Central: efeitos do desmatamento sobre as populações. Acta Amazonica, v.9, n.3, p.481-499,1979.

BANDEIRA, A.G.; VASCONCELLOS, A. A quantitative survey of termites in a gradient of disturbed highland forest in Northeastern Brazil. Sociobiology, v.39, n.3, p.429-439, 2002.

BANDEIRA, A.G.; VASCONCELLOS, A.; SILVA, M.P.; CONSTANTINO, R. Effects of habitat disturbance on the termite fauna in a highland forest in the Caatinga Domain, Brazil. Sociobiology, v.42, n.1, p.117-127, 2003.

BEGON, M.; HARPER, J.L.; TOWNSEND, C.R. Ecology: individuals, populations and communities. London: Blackwell Scientific, 1990, 945p.

BERTI FILHO, E. Cupins e florestas. In: BERTI FILHO, E.; FONTES, L.R. (Ed.). Alguns aspectos atuais da biologia e controle de cupins. Piracicaba: FEALQ, 1995. p.127-140.

BIGNELL, D.E.; EGGLETON, P. Termites in ecosystems. In: ABE, T.; BIGNELL, D.E.; HIGASHI, M. Termites: evolution, sociality, symbioses, ecology. Nordrecht: Kluwer Academic, 2002. cap.17, p.363-387. 
CAMPOS, M.B.S.; ALVES, S.B.; MACEDO, N. Seleção de iscas celulósicas para o cupim Heterotermes tenuis (Isoptera: Rhinotermitidae) em cultura de cana-de-açúcar. Scientia Agricola, v.55, n.3, p.480-484, 1998.

CANCELLO, E.M. Revisão de Procornitermes Emerson (Isoptera, Termitidae, Nasutitermitinae). Papéis Avulsos de Zoologia, v.36, n.19, p.189-236, 1986.

CANCELLO, E.M. Revisão de Cornitermes Wasmann (Isoptera, Termitidae, Nasutitermitinae). São Paulo, 1989. 151p. Tese (Doutorado) - Instituto de Biociências, Universidade de São Paulo.

CANCELLO, E.M. Termite diversity along the Brazilian Atlantic Forest. In: INTERNATIONAL CONGRESS OF IUSSI, 14., Sapporo, 2002. Proceedings. Sapporo: Hokkaido University Coop., 2002. p.164.

CASTRO, Z.S.C.; DIEHL, E. Gêneros de térmitas em ninhos epígeos no campus da Unisinos, São Leopoldo, RS. Acta Biologica Leopoldensia, v.25, n.1, p. 93-102, 2003.

COLLINS, N.M. The role of termites in the decomposition of wood and leaf litter in the southern Guinea Savanna of Nigeria. Oecologia, v.51, p. 389-399, 1981.

CONSTANTINO, R. Abundance and diversity of termites (Insecta: Isoptera) in two sites of primary rain forest in Brazilian Amazonia. Biotropica, v.24, n.3, p.420-430, 1992.

CONSTANTINO, R. Catalog of the living termites of the New World (Insecta: Isoptera). Arquivos de Zoologia, v.35, n.2, p.135-231, 1998. 
CONSTANTINO, R. Chave ilustrada para identificação dos gêneros de cupins (Insecta: Isoptera) que ocorrem no Brasil. Papéis Avulsos de Zoologia, v.40, n.25, p. 387-448, 1999.

CONSTANTINO, R.; SCHLEMMERMEYER, T. Cupins. In: ALHO, C. J. R. (Ed.). Fauna silvestre da região do rio Manso, M.T. Brasília: IBAMA, 2000. p.129-151.

COWIE, R.H.; LOGAN, J.W.M.; WOOD, T.G. Termite (Isoptera) damage and control in tropical forestry with special reference to Africa and Indo-Malaysia: a rewiew. Bulletin of Entomological Research, v.79, p.173-184, 1989.

DAVIES, R.G.; EGGLETON, P.; DIBOG, L.; LAWTON, J.H.; BIGNELL, D.E.; BRAUMAN, A.; HARTMANN, C.; NUNES, L.; HOLT, J.; ROULAND, C. Successional response of a tropical forest termite assemblage to experimental habitat perturbation. Journal of Applied Ecology, v.36, p.946962, 1999.

De SOUZA, O.F.; BROWN, V.K. Effects of habitat fragmentation on Amazonian termite communities. Journal of Tropical Ecology, v.10, p.197-206, 1994.

DIBOG, L.; EGGLETON, P.; NORGROVE, L.; BIGNELL, D.E.; HAUSER, S. Impacts of canopy cover on soil termite assemblages in an agrisilvicutural system in southern Cameroon. Bulletin of Entomological Research, v.89, p.125-132, 1999. 
DIETRICH, C.R.R.C. Ocorrência de cupins (Insecta: Isoptera) em reflorestamento de Eucalyptus spp. Piracicaba, 1989. 68p. Dissertação (Mestrado) - Escola Superior de Agricultura "Luiz de Queiroz", Universidade de São Paulo.

DOMINGOS, D.J.; GONTIJO, T.A.; CAVENAGHI, T.M.C.M. Uso diferencial de madeiras por térmitas em cerrado. Brasil Florestal, n.66, p.26-31, 1988.

EGGLETON, P.; BIGNELL, D.E.; SANDS, W.A.; WAITE, B.; WOOD, T.G.; LAWTON, J.H. The species richness of termites (Isoptera) under differing levels of forest disturbance in the Mbalmayo Forest Reserve, southern Cameroon. Journal of Tropical Ecology, v.11, p.85-98, 1995.

EGGLETON, P.; BIGNELL, D.E.; SANDS, W.A.; MAWDSLEY, N.A.; LAWTON, J.H.; WOOD, T.G.; BIGNELL, N.C. The diversity, abundance and biomass of termites under differing levels of disturbance in the Mbalmayo Forest Reserve, southern Cameroon. Philosophical Transactions of the Royal Society, Serie B, v.351, p.51-68, 1996.

EGGLETON, P.; HOMATHEVI, R.; JEEVA, D.; JONES, D.T.; DAVIES, R.G.; MARYATI, M. The species richness and composition of termites (Isoptera) in primary and regenerating lowland dipterocarp forest in Sabah east Malaysia. Ecotropica, v.3, p.119-128, 1997.

EGGLETON, P.; DAVIES, R.G.; BIGNELL, D.E. Body size and energy use in termites (Isoptera): the responses of soil feeders and wood feeders differ in a tropical forest assemblage. Oikos, v.81, p.525-530, 1998. 
FONSECA, J.P. Experiências de combate químico a cupins subterrâneos no Horto Florestal de Guarani. Arquivos do Instituto Biológico, v.19, p.57-84, 1949.

FONTES, L.R. Acréscimos e correções ao "Catálogo dos Isoptera do Novo Mundo". Revista Brasileira de Entomologia, v.27, n.2, p.137-145, 1983.

FONTES, L.R. New genera and new species of Nasutitermitinae from the Neotropical region (Isoptera, Termitidae). Revista Brasileira de Zoologia, v.3, n.1, p.7-25, 1985.

FONTES, L.R. Sistemática geral de cupins. In: BERTI FILHO, E.; FONTES, L.R. (Ed.). Alguns aspectos atuais da biologia e controle de cupins. Piracicaba: FEALQ, 1995. p.11-17.

FONTES, L.R.; MONTEIRO, A.R. Etimologia e pronúncia dos nomes científicos dos cupins. In: FONTES, L. R.; BERTI FILHO, E. (Ed.). Cupins: o desafio do conhecimento. Piracicaba: FEALQ, 1998. p. 19-43.

GONTIJO, T.A.; DOMINGOS, D.J. Guild distribution of some termites from cerrado vegetation in South-east Brazil. Journal of Tropical Ecology, v.7, p.523-529, 1991.

GRASSÉ, P.P. Ordres des Isoptères ou Termites. In: GRASSÉ, P.P. (Ed). Traité de zoologie, anatomie, systématique, biologie. Paris: Masson,1949. p. $408-544$.

GRASSÉ, P.P. Termitologia: anatomie - physiologie - biologie - systématique des termites. Paris: Masson, 1982. v.1, 676p. 
GRASSÉ, P.P. Termitologia: fondation des sociétés construction. Paris: Masson, 1984. v.2, 613p.

GRASSÉ, P.P. Termitologia: comportement - socialité - écologie - évolution systématique. Paris: Masson, 1985. v.3, 716p.

HARRIS, W.V. Termites: their recognition and control. 2.ed. London: Longman, 1971.186p.

JONES, D.T. Termite assemblages in two distinct montane forest types at 1000 $\mathrm{m}$ elevation in the Maliau Basin, Sabah. Journal of Tropical Ecology, v.16, p.271-286, 2000.

JONES, D.T.; BRENDELL, M.J.D. The termite (Insecta: Isoptera) fauna of Pasoh Forest Reserve, Malaysia. Raffles Bulletin of Zoology, v.46, p.79-91, 1998.

JONES, D.T.; EGGLETON, P. Sampling termite assemblages in tropical forests: testing a rapid biodiversity assessment protocol. Journal of Applied Ecology, v.37, p.191-203, 2000.

JONES, D.T.; SUSILO, F.X.; BIGNELL, D.E.; HARDIWINOTO, S.; GILLISON, A.N.; EGGLETON, P. Termite assemblage collapse along a land-use intensification gradient in lowland central Sumatra, Indonesia. Journal of Applied Ecology, v.40, p.380-391, 2003. 
JUNQUEIRA, L.K. Cupins (Insecta: Isoptera) em plantios de Eucalyptus spp. (Myrtaceae) na Estação Experimental de Ciências Florestais da Universidade de São Paulo, no município de Anhembi, São Paulo. Piracicaba, 1999. 57p. Dissertação (Mestrado) - Escola Superior de Agricultura "Luiz de Queiroz", Universidade de São Paulo.

JUNQUEIRA, L.K.; BERTI FILHO, E. Termite (Insecta: Isoptera) in plantings of Eucalyptus spp. (Myrtaceae) in Anhembi, state of São Paulo, Brazil. Acta Biologica Leopoldensia, v.22, n.2, p.205-21, 2000.

KRISHNA, K.; WEESNER, F.M. Biology of termites. New York: Academic Press, 1969. v. 1, 598p.

KRISHNA, K.; WEESNER, F.M. Biology of termites. New York: Academic Press, 1970. v. 2, 643p.

LAVELLE, P.; BIGNELL, D.; LEPAGE, M.; WOLTERS, V.; ROGER, P.; INESON, P.; HEAL, O.W.; DHILLION, S. Soil function in a changing world: the role of invertebrate ecosystem engineers. European Journal of Soil Biology, v.33, n.4, p.159-193, 1997.

LEE, K.E.; WOOD, T.G. Termites and soils. London: Academic Press, 1971. $251 \mathrm{p}$.

MAGURRAN, A.E. Ecological diversity and its measurement. Englewood Cliffs: Princeton University Press, 1988. 179p.

MARICONI, F.A.M. Inseticidas e seu emprego no combate às pragas. 4.ed. São Paulo: Nobel, 1981. 2v. 
MARTIUS, C. Diversity and ecology of termites in Amazonian forests. Pedobiologia, v.38, p.407-428, 1994.

MATHEWS, A.G.A. Studies on termites from the Mato Grosso State, Brazil. Rio de Janeiro: Academia Brasileira de Ciências, 1977. 267p.

MILL, A.E. Populações de térmitas (Insecta:Isoptera) em quatro habitats no baixo rio Negro. Acta Amazonica, v.12, n.1, p.53-60, 1982.

MILL, A.E. Generic keys to the soldier caste of the New World Termitidae (Isoptera: Insecta). Systematic Entomology, v.8, p.179-190, 1983.

MORAES, R.C.B.; HADDAD, M.L.; SILVEIRA NETO, S.; REYES, A.E.L. Software para análise faunística - ANAFAU. In: SIMPÓSIO DE CONTROLE BIOLÓGICO, 8., São Pedro, 2003. Resumos. São Pedro: Sociedade Entomológica do Brasil, 2003. p.195.

NAIR, K.S.S.; VARMA, R.V. Some ecological aspects of the termite problem in young eucalypt plantations in Kerala, India. Forest Ecology and Management, v.12, p.287-303, 1985.

NOGUEIRA, S.B.; SOUZA, A.J. "Cupim do cerne", Coptotermes testaceus (Isoptera: Rhinotermitidae), uma praga séria para eucaliptos nos cerrados. Brasil Florestal, n.61, p.27-29, 1987.

ODUM, E.P. Ecologia. Rio de Janeiro: Guanabara Koogan, 1988. 434p. 
OLIVEIRA, E.P.; ACIOLI, A.N.S. Diversidade de Isoptera (Insecta) em áreas recuperadas com árvores nativas após extração de bauxita (Pará). In: CONGRESSO BRASILEIRO DE ENTOMOLOGIA, 19., Manaus, 2002. Resumos. Manaus: Sociedade Entomológica do Brasil, 2002. p.199.

PAPA, G.; HARO, N.H. Efeito de uma formulação especial de inseticida granulado sobre o controle de cupins, Cornitermes sp. (Isoptera: Termitidae) no plantio de eucalipto. In: CONGRESSO BRASILEIRO DE ENTOMOLOGIA, 13., Recife, 1991. Resumos. Recife: Sociedade Entomológica do Brasil, 1991. p.505.

PIZANO, M.A.; FONTES, L.R. Ocorrência de Heterotermes tenuis (Hagen, 1858) e $H$. longiceps (Snyder, 1924) (Isoptera, Rhinotermitidae) atacando cana-de-açúcar no Brasil. Brasil Açucareiro, v.104, n.3/4, p.29, 1986.

RAETANO, C.G.; WILCKEN, C.F.; CROCOMO, W.B. Controle de cupins em florestas de eucalipto com o inseticida fipronil (Regent $20 \mathrm{G}$ ) aplicado em cobertura. Revista Árvore, v.21, n.2, p.289-293, 1997.

REIS, Y.T.; CANCELLO, E.M. Diversidade de Isoptera em duas áreas de Mata Atlântica do sudeste da Bahia. In: CONGRESSO BRASILEIRO DE ENTOMOLOGIA, 19., Manaus, 2002. Resumos. Manaus: Sociedade Entomológica do Brasil, 2002. p.206.

RICKLEFS, R.E. A economia da natureza. 3.ed. Rio de Janeiro: Guanabara Koogan, 1996. 470p.

SANTOS, G.M.M.; MARQUES, O.M. Análise faunística de comunidades de formigas epigéias (Hymenoptera, Formicidae) em dois agroecossistemas em Cruz das Almas - Bahia. Insecta, v.5, n.1, p.1-17, 1996. 
SANTOS, G.P.; ZANUNCIO, J.C.; ANJOS, N.; ZANUNCIO, T.V. Danos em povoamentos de Eucalyptus grandis pelo cupim do cerne Coptotermes testaceus Linnè, 1785 (Isoptera: Rhinotermitidae). Revista Árvore, v.14, n.2, p.155-163, 1990.

SENA, J.M.; VASCONCELLOS, A.; GUSMAO, M.A.B.; BANDEIRA, A.G. Assemblage of termites in a fragment of cerrado on the coast of Paraíba State, Northeast Brazil. Sociobiology, v.42, n.3, p.753-760, 2003.

SILVEIRA NETO, S.; MONTEIRO, R.C.; ZUCCHI, R.A.; MORAES, R.C.B. Uso da análise faunística de insetos na avaliação do impacto ambiental. Scientia Agricola, v.52, n.1, p.9-15, 1995.

THOMAZINI, M.J.; THOMAZINI, A.P.B.W. Diversidade de cupins em diferentes gradientes de sucessão ecológica no sudeste do Estado do Acre. In: CONGRESSO BRASILEIRO DE ENTOMOLOGIA, 19., Manaus, 2002. Resumos. Manaus: Sociedade Entomológica do Brasil, 2002. p.217.

WARDELL, D.A. Control of termites in nurseries and young plantations in Africa: established practices and alternative courses of action. Commonwealth Forest Review, v.66, n.1, p.77-89, 1987.

WILCKEN, C.F. Danos de cupins subterrâneos Cornitermes sp. (Isoptera: Termitidae) em plantios de Eucalyptos grandis e controle com inseticidas no solo. Anais da Sociedade Entomológica do Brasil, v.21, n.3, p.329-338, 1992. 
WILCKEN, C.F.; RAETANO, C.G. Controle de cupins em florestas. In: BERTI FILHO, E.; FONTES, L.R. (Ed.). Alguns aspectos atuais da biologia e controle de cupins. Piracicaba: FEALQ, 1995. p.141-154.

WILCKEN, C.F.; RAETANO, C.G. Eficiência da bifentrina no controle de cupins subterrâneos (Isoptera: Termitidae) em plantios de eucalipto. In: CONGRESSO BRASILEIRO DE ENTOMOLOGIA, 16., Salvador, 1997. Resumos. Salvador: Sociedade Entomológica do Brasil, 1997. p.225.

WILCKEN, C.F.; RAETANO, C.G. Atualidades no controle de cupins em florestas de eucalipto. In: FONTES, L.R.; BERTI FLIHO, E. (Ed.). Cupins: o desafio do conhecimento. Piracicaba: FEALQ, 1998. p.173-185.

WILSON, E.O. Sociobiologia: la nueva sintéses. Barcelona: Omega, 1980. $701 p$.

WOOD, T.G.; JOHNSON, R.A.; BACCHUS, S.; SHITTU, M.O.; ANDERSON, J.M. Abundance and distribution of termites (Isoptera) in a Riparian forest in the Southern Guinea savanna vegetation zone of Nigeria. Biotropica, v.14, p.25-39, 1982. 